Prepared for the U.S. Department of Energy

under Contract DE-AC05-76RL01830

\title{
Caustic Recycle from Hanford Tank Waste Using NaSICON Ceramic Membrane Salt Splitting Process
}
MS Fountain
J Pendleton
DE Kurath S Balagopal
GJ Sevigny M Quist
AP Poloski
D Clay

February 2009 


\title{
DISCLAIMER
}

This report was prepared as an account of work sponsored by an agency of the United States Government. Neither the United States Government nor any agency thereof, nor Battelle Memorial Institute, nor any of their employees, makes any warranty, express or implied, or assumes any legal liability or responsibility for the accuracy, completeness, or usefulness of any information, apparatus, product, or process disclosed, or represents that its use would not infringe privately owned rights. Reference herein to any specific commercial product, process, or service by trade name, trademark, manufacturer, or otherwise does not necessarily constitute or imply its endorsement, recommendation, or favoring by the United States Government or any agency thereof, or Battelle Memorial Institute. The views and opinions of authors expressed herein do not necessarily state or reflect those of the United States Government or any agency thereof.

\author{
PACIFIC NORTHWEST NATIONAL LABORATORY \\ operated by \\ BATTELLE \\ for the \\ UNITED STATES DEPARTMENT OF ENERGY \\ under Contract DE-AC05-76RL01830
}

Printed in the United States of America
Available to DOE and DOE contractors from the Office of Scientific and Technical Information,
P.O. Box 62, Oak Ridge, TN 37831-0062;
ph: (865) 576-8401
fax: $(865)$ 576-5728
email: reports@adonis.osti.gov

\begin{abstract}
Available to the public from the National Technical Information Service, U.S. Department of Commerce, 5285 Port Royal Rd., Springfield, VA 22161 ph: (800) 553-6847 fax: $(703) 605-6900$ email: orders@ntis.fedworld.gov online ordering: http://www.ntis.gov/ordering.htm
\end{abstract}

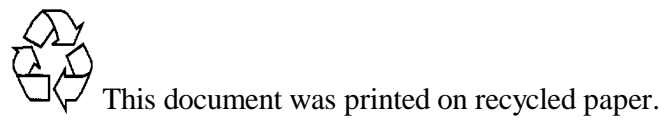




\title{
Caustic Recycle from Hanford Tank Waste Using NaSICON Ceramic Membrane Salt Splitting Process
}

\author{
MS Fountain \\ J Pendleton ${ }^{1}$ \\ DE Kurath \\ GJ Sevigny \\ S Balagopal ${ }^{1}$ \\ M Quist ${ }^{1}$ \\ AP Poloski \\ D Clay $^{1}$
}

February 2009

Prepared for

the U.S. Department of Energy

under Contract DE-AC05-76RL01830

Pacific Northwest National Laboratory

Richland, Washington 99352

\footnotetext{
${ }^{1}$ Ceramatec Inc., Salt Lake City, Utah
} 



\section{Summary}

A family of inorganic ceramic materials, called sodium (Na) Super Ion Conductors (NaSICON), has been studied at Pacific Northwest National Laboratory (PNNL) to investigate their ability to separate sodium from radioactively contaminated sodium salt solutions for treating U.S. Department of Energy (DOE) tank wastes. Ceramatec Inc. developed and fabricated a membrane containing a proprietary NASGY material formulation that was electrochemically tested in a bench-scale apparatus with both a simulant and a radioactive tank-waste solution to determine the membrane performance when removing sodium from DOE tank wastes. Implementing this sodium separation process can result in significant cost savings ${ }^{1}$ by reducing the disposal volume of low-activity wastes and by producing a $\mathrm{NaOH}$ feedstock product for recycle into waste treatment processes such as sludge leaching, regenerating ion exchange resins, inhibiting corrosion in carbon-steel tanks, or retrieving tank wastes.

This report presents the results of the actual waste tests associated with an NAS-GY formulation of the ceramic membrane and the electrochemical cell design incorporating the membranes. Conclusions from these experiments are as follows:

- Sodium transport efficiencies ranged from 88 to $102 \%$ while average efficiencies were $93 \%$ (nonradioactive test) and $99 \%$ (both radioactive tests). The membrane appears to undergo an initial "break-in" period, which is assumed to be a transition from an unsaturated to a saturated $\mathrm{Na}$ channel network.

- All three experiments produced $\mathrm{Na}$ transport rates in good agreement with theoretical $\mathrm{Na}$ transport rates based on applied current. Average Na separation rates of $9.6 \mathrm{~kg} / \mathrm{day} / \mathrm{m}^{2}$ (simulant$1 \mathrm{M} \mathrm{NaOH}), 10.3 \mathrm{~kg} / \mathrm{day} / \mathrm{m}^{2}(\mathrm{rad}-1 \mathrm{M} \mathrm{NaOH})$, and $10.3 \mathrm{~kg} /$ day $/ \mathrm{m}^{2}(\mathrm{rad}-18.6 \mathrm{M} \mathrm{NaOH})$ were observed.

- The NAS-GY membrane is highly selective to sodium. No transport of any cations or anions was detected except for $\mathrm{Na}$ and ${ }^{137} \mathrm{Cs}$. Decontamination factors on the order of 2000 were observed with respect to ${ }^{137} \mathrm{Cs}$.

- ICP-OES measurements clearly indicated $\mathrm{Na}$ ion transport, but also identified a decreased concentration of $\mathrm{Al}, \mathrm{Ca}$, and $\mathrm{Si}$ in the samples taken after the large voltage increases occurred.

- The electrochemical cell system successfully produced a $19 \mathrm{M} \mathrm{NaOH}$ solution with no observable membrane performance loss. In addition, concentrating the $\mathrm{NaOH}$ product to $19 \mathrm{M} \mathrm{NaOH}$ satisfies the feedstock caustic requirement of DOE's WTP and would eliminate the need for a process evaporator when using other separation technologies.

- The anion waste composition of the anolyte reservoir was relatively stable. There was no discernable transport or composition changes related to $\mathrm{F}^{-}, \mathrm{Cl}^{-}, \mathrm{NO}_{2}^{-}, \mathrm{NO}_{3}^{-}, \mathrm{SO}_{4}^{-2}, \mathrm{CrO}_{4}^{-2}$, and $\mathrm{PO}_{4}^{-3}$ anions except approximately $30 \%$ of the original $\mathrm{NO}_{2}{ }^{-}$anions were oxidized to $\mathrm{NO}_{3}{ }^{-}$anions.

- A maximum recoverable sodium quantity could be predicted by combining both an aluminate solubility model and a gibbsite crystal growth rate. Testing shows cell voltages were relatively

\footnotetext{
${ }^{1}$ Poloski AP, DE Kurath, LK Holton, G Sevigny and M Fountain. 2008. Economic Feasibility of Electrochemical Caustic Recycling at the Hanford Site. Draft Report, Pacific Northwest National Laboratory, Richland, Washington.
} 
stable until saturation ratios exceeded 9 (sharp increase in voltage), and the cell was successfully operated at saturation ratios as high as 12 . 


\section{Acknowledgments}

The authors would like to acknowledge the following people for their significant contributions:

Marilyn Steele (PNNL), Susan Jones (PNNL), Mark Flinders (Ceramatec Inc.). Also, for a thorough and quality technical review, the authors thank Jagan Bontha (PNNL).

This work is funded through a sub-contract from Ceramatec Inc. who is funded by the Office of Science and Technology within the U.S. Department of Energy's Office of Environmental Management under contract DE-FG07-04ID14622. Pacific Northwest National Laboratory is operated for the U.S. Department of Energy by Battelle under Contract DE-AC05-76RL01830. 



\section{Acronyms and Abbreviations}

$\begin{array}{ll}\text { AC } & \text { alternating current } \\ \text { CA } & \text { contamination area } \\ \text { DC } & \text { direct current } \\ \text { DDI } & \text { deionized, distilled water } \\ \text { Df } & \text { Decontamination factor } \\ \text { DOE } & \text { U.S. Department of Energy } \\ \text { EPDM } & \text { ethylene-propylene-diene monomer } \\ \text { GEA } & \text { gamma energy analysis } \\ \text { HDPE } & \text { high-density polyethylene } \\ \text { HLW } & \text { high-level waste } \\ \text { IC } & \text { ion chromatography } \\ \text { ICP } & \text { inductively coupled plasma } \\ \text { MP } & \text { multi-purpose } \\ \text { NaSICON } & \text { (Na) Super Ion Conductor } \\ \text { OES } & \text { optical emission spectrometry } \\ \text { PNNL } & \text { Pacific Northwest National Laboratory } \\ \text { PP } & \text { polypropylene } \\ \text { PTFE } & \text { polytetrafluoroethylene } \\ \text { RE-NaSICON } & \text { rare-earth (Na) Super Ion Conductor } \\ \text { TIC } & \text { total inorganic carbon } \\ \text { TOC } & \text { total organic carbon } \\ \text { WTP } & \text { Waste Treatment Plant } \\ \text { XRD } & \text { X-ray diffraction }\end{array}$





\section{Contents}

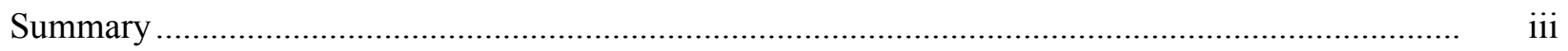

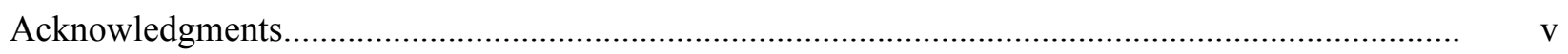



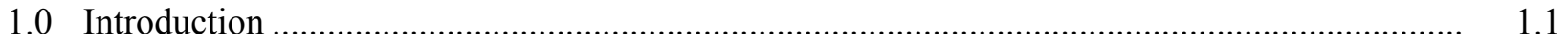

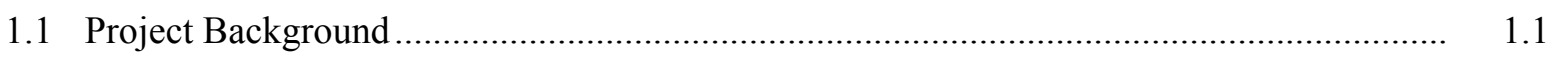

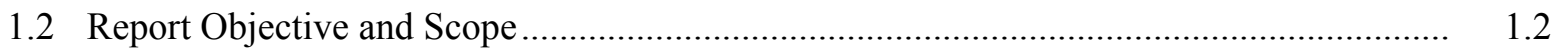

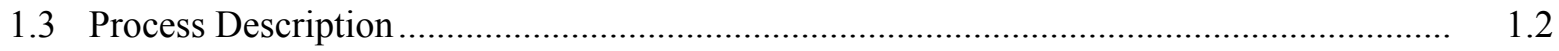

1.4 Materials Development and Testing Strategy .......................................................... 1.4

2.0 Experimental Apparatus and Procedure ............................................................................ 2.1

2.1 Membrane Fabrication, Composition, and Dimensions ................................................ 2.1

2.2 Bench-Scale Electrochemical Test System .............................................................. 2.1

2.3 Feed Compositions and Simulant Preparation .......................................................... 2.4

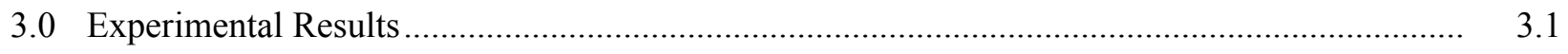

3.1 Bench-Scale Testing of NAS-GY Single Disk ............................................................. 3.1

3.1.1 Simulant Testing ......................................................................................... 3.1

3.1.2 AP104/SY101/AZ101 Radioactive Anolyte Test \#1 (1 M NaOH Catholyte) .......... 3.3

3.1.3 AP104/SY101/AZ101 Radioactive Anolyte Test \#2 (18.6 M NaOH catholyte) ...... 3.5

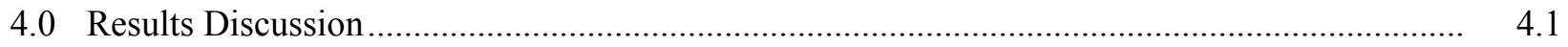

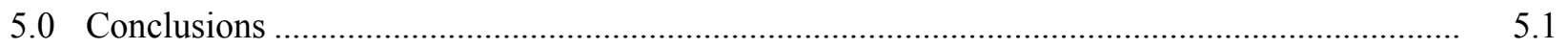

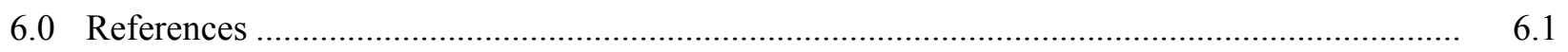




\section{Figures}

Figure 1.1. Schematic of an Electrochemical Process Using the NaSICON Membrane ......................... 1.3

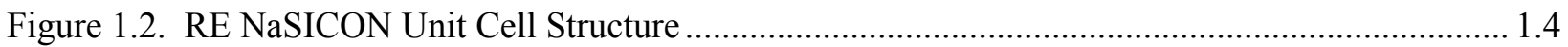

Figure 2.1. Bench-Scale Electrochemical Salt-Splitting System ..................................................... 2.2

Figure 2.2. Bench-Scale Electrochemical Cell System: Electro MP (Electro Cell AB) ........................ 2.3

Figure 2.3. Picture of AP104/SY101/AZ101 Tank Waste Sample ...................................................... 2.5

Figure 2.4. Picture of AP104/SY101/AZ104 Waste Simulant ............................................................. 2.6

Figure 3.1. Voltage and Current Density During Simulant Testing …............................................... 3.2

Figure 3.2. Sodium Transport Rate Comparison During Simulant Testing.......................................... 3.3

Figure 3.3. Voltage and Current Density during Radioactive Test \#1 (1 M NaOH Catholyte)................ 3.4

Figure 3.4. Sodium Transport Rate Comparison during Radioactive Test \#1 (1 M NaOH Catholyte) .... 3.5

Figure 3.5. Voltage and Current Density during Radioactive Test \#2 (18.6 M NaOH Catholyte)........... 3.6

Figure 3.6. Sodium Transport Rate Comparison during Radioactive Test \#2

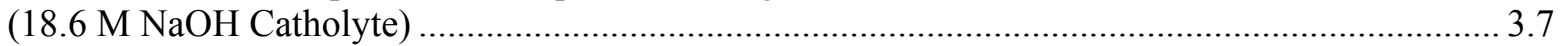

Figure 4.1. Current Density and Voltage Behavior over Three Test Case History................................. 4.2

Figure 4.2. Comparison of Sodium Current Efficiency Between Tests............................................... 4.3

Figure 4.3. Experimentally Measured Crystal Growth Rates of Saturated Sodium Aluminate Solutions at $22^{\circ} \mathrm{C}$

Figure 4.4. Voltage and Current Density as a Function of Saturation Ratio during Rad Test \#1 ............ 4.7

Figure 4.5. Voltage and Current Density as a Function of Saturation Ratio during Rad Test \#2 ............ 4.7

\section{Tables}

2.1 AP104/SY101/AZ101 Tank Waste Initial Composition ........................................................ 2.4

2.2 AP104/SY101/AZ101 Simulant Initial Composition ............................................................ 2.6

3.1 Summary of Simulant Testing Experimental Conditions ...................................................... 3.2

3.2 Summary of Radioactive Test \#1 Experimental Conditions..................................................... 3.3

3.3 Summary of Radioactive Test \#2 Experimental Conditions...................................................... 3.5

4.1 Summary of Process Parameters For All Experiments ............................................................. 4.2

4.2 Radionuclide Analysis and Decontamination Factors ......................................................... 4.4

4.3 Cation Concentration Decrease in Anolyte.......................................................................... 4.5 


\subsection{Introduction}

\subsection{Project Background}

Producing nuclear materials within the U.S. Department of Energy (DOE) complex generated acidic waste streams that were made highly alkaline by adding sodium hydroxide for storage in carbon-steel tanks. Many of the wastes are therefore dominated by non-radioactive sodium that can negatively affect waste treatment and disposal operations. Sodium is the primary contributor to large disposal volumes of low-activity waste, because it decreases the durability of waste forms such as glass. Waste-treatment processes, such as cesium ion exchange, sludge washing, and calcination, are made less efficient and more expensive because of the high $\mathrm{Na}$ concentrations.

Some proposed pretreatment processing strategies (Kirkbride et al. 1997, Davis 1998, Kirkbride et al. 2005) call for adding more $\mathrm{Na}$ (primarily as $\mathrm{NaOH}$ ) to the wastes. For example, adding $\mathrm{NaOH}$ is proposed to enhance the sludge-leaching process to leach Al from the high-level waste (HLW) process stream. Also, more importantly, $\mathrm{NaOH}$ additions are proposed to prevent solids precipitation. These $\mathrm{Na}$ additions, unless removed, will ultimately increase the quantity of waste processed. Separating and recycling $\mathrm{Na}$ from the radioactive wastes can potentially reduce costs by reducing the low-activity waste disposal volumes, improving the efficiency of the waste-treatment processes, and avoiding the need to procure additional chemicals.

In the late 1990s, a multi-step development and testing process for sodium (Na) Super Ion Conductors (NaSICON) membrane materials was completed at Pacific Northwest National Laboratory (PNNL). The initial step was to screen the materials by determining the sodium ionic conductivity in static (non-flowing) cells using a combination of DC-pulse (current interrupt) and AC-impedance techniques. Materials with the greatest sodium ionic conductivity were subjected to long-term testing in single disk electrochemical cells to assess the chemical and electrochemical stability of the materials and to determine the long-term sodium transport efficiency. The membrane compositions with the best combination of ionic conductivity and lifetime were incorporated into the multi-disk scaffolds for benchand pilot-scale testing.

Several different membrane compositions and three different disk sizes were tested. The initial materials investigated were RE-NaSICON compositions based on the rare-earth elements dysprosium (Dy-NaSICON) and neodymium (Nd-NaSICON). The new family of NaSICON and doped NaSICON compositions tested were denoted NAS-D, NAS-E, NAS-G, and NAS-H where the letters D, E, G, and H denote a given class of compositions. A variable $\mathrm{X}$ is used to denote the concentration of various dopants (e.g., NAS-D 10). These compositions were developed to increase the sodium transport rate by increasing the channel size for sodium ion conduction. The $\mathrm{X}$ dopant in the composition provides chemical and electrochemical stability toward corrosion. Membranes were fabricated with diameters of $2.54 \mathrm{~cm}, 3.9 \mathrm{~cm}$, and $5.1 \mathrm{~cm}$ and a thickness that is typically 1.4 to $1.5 \mathrm{~mm}$. Disks as thin as $0.7 \mathrm{~mm}$ were fabricated and tested in an effort to reduce the resistance of the membranes to ionic conduction and thereby lower the voltage drop across the membrane. 
Through experimental work, it was discovered that these new materials were 2.5 (NAS-E) to 4 (NAS-G) to 5 (NAS-H) times more conductive than the NAS-D materials. The sodium ion transport efficiencies were generally greater than $90 \%$. The NAS-G membranes were tested at current densities as high as $400 \mathrm{~mA} / \mathrm{cm}^{2}$. Both the NAS-E and NAS-G membranes were found to be susceptible to weakening and failure after about 500 hours in tests with Hanford waste simulants. Failure was thought to be due to ion-exchange-induced corrosion in which $\mathrm{K}^{+}$exchanges with $\mathrm{Na}^{+}$in the material structure.

Additional membranes were developed within the NAS-G family of membranes to produce an improved NAS-GY (876GY) material with attractive chemical and electrochemical stability. Extensive testing of the NAS-G membranes was conducted by Ceramatec Inc., but these materials were only subjected to waste simulants and no actual tank-waste samples.

PNNL was recently solicited to conduct bench-scale testing of an NAS-GY membrane, $1.4 \mathrm{~mm}$ thick and $7.62 \mathrm{~cm}$ diameter, using an actual tank-waste sample. Three experiments were conducted, one with a non-radiological waste simulant and two with a composited sample of AP104/SY101/AZ101 tank waste from the Hanford site.

\subsection{Report Objective and Scope}

This report presents a summary of membrane testing activities associated with separating and recycling sodium from radioactive wastes. Testing activities include bench-scale testing with nonradioactive tank waste simulants and actual radioactive tank wastes at the Hanford site.

\subsection{Process Description}

An electrochemical salt-splitting process based on inorganic ceramic membranes is shown in Figure 1.1. This process shows promise as a means to mitigate the impact of $\mathrm{Na}$ by enabling the separation and recycling of $\mathrm{Na}$ from the radioactive wastes. In this process, the waste is added to the anode compartment, and an electrical potential is applied to the cell. The ceramic membrane allows the selective transport of $\mathrm{Na}^{+}$ions to the cathode compartment while most other cations (e.g., $\left.\mathrm{K}^{+}, \mathrm{Cs}^{+}\right)$and anions are left behind (i.e., rejected) in the anode compartment. The charge balance in the anode compartment is maintained by generating $\mathrm{H}^{+}$from the electrolysis of water. The charge balance in the cathode is maintained by generating $\mathrm{OH}^{-}$, either from the electrolysis of water or from oxygen and water using an oxygen gas diffusion cathode. The normal gaseous products of the electrolysis of water are oxygen at the anode and hydrogen at the cathode. Potentially flammable gas mixtures can be prevented by providing adequate volumes of a sweep gas, using an alternative reductant, or destroying the hydrogen as it is generated. As $\mathrm{H}^{+}$is generated in the anode compartment, the $\mathrm{pH}$ drops. Producing $\mathrm{OH}^{-}$in the cathode compartment results in a rise in $\mathrm{pH}$ as the $\mathrm{Na}$ hydroxide product is produced. 

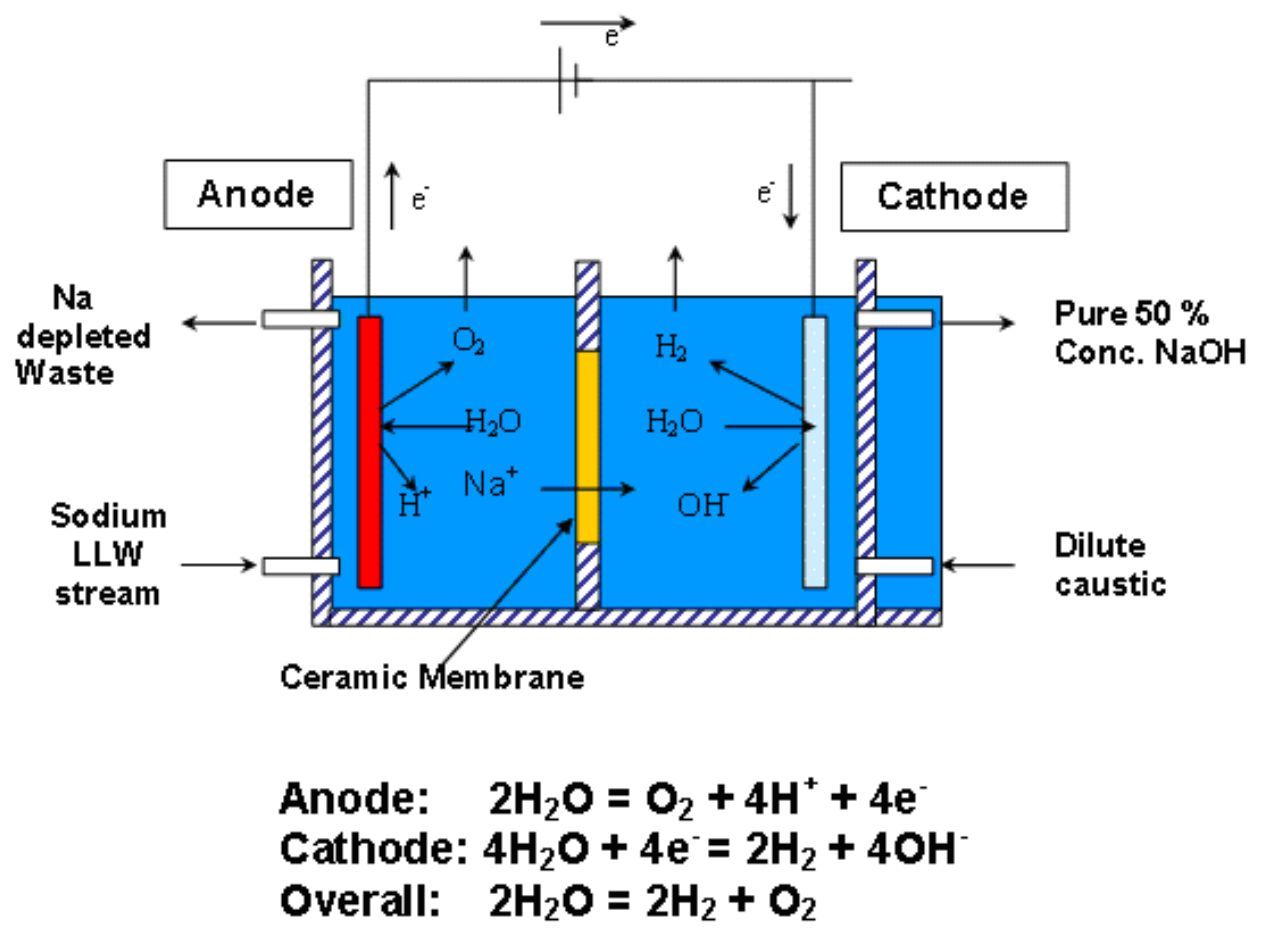

Figure 1.1. Schematic of an Electrochemical Process Using the NaSICON Membrane

The Na-ion selective ceramic membranes are from a family of materials known in the electrical battery industry as NaSICON. An initial investigation conducted by Ceramatec in 1990 demonstrated the feasibility of using membranes based on the composition $\mathrm{Na}_{3} \mathrm{Zr}_{2} \mathrm{Si}_{2} \mathrm{PO}_{12}$ for salt splitting (Sutija et al. 1996). While Na selectivity was found to be high, the Na conductivity was judged to be too low for commercial application. Subsequent materials development indicated that ceramics based on the composition $\mathrm{Na}_{5} \mathrm{RESi}_{4} \mathrm{O}_{12}$ (RE-NaSICON), where RE is yttrium or a rare-earth element, had a higher conductivity and resistance to corrosion. The best RE-NaSICON materials developed to date are based on the rare earths dysprosium and neodymium. A new family of materials has been developed that exhibits additional improvement in the membrane properties, especially the ionic conductivity and the lifetime. This family of materials is designated NAS-D, NAS-E, NAS-G, etc. and may include adding dopants to increase the chemical and electrochemical stability of the materials. Within this newer family of NaSICON materials, it was discovered that NAS-E and NAS-G types were 2.5 and 4.0 times more conductive than the NAS-D materials, respectively.

The NaSICON ceramics are polycrystalline materials that possess channels within the crystal structure for $\mathrm{Na}$ ion conduction. The RE-NaSICON unit cell structure (Maximov et al. 1982) is shown in Figure 1.2. Silica tetrahedra "rings" and sodium and heavy metal ions form the structure around these channels, which are filled with highly mobile $\mathrm{Na}$ ions. The channel size is determined by the rare-earth ion. These materials are uni-dimensional ionic conductors, so the grain orientation affects the ionictransport rates. The new NaSICON materials are three-dimensional ionic conductors. 


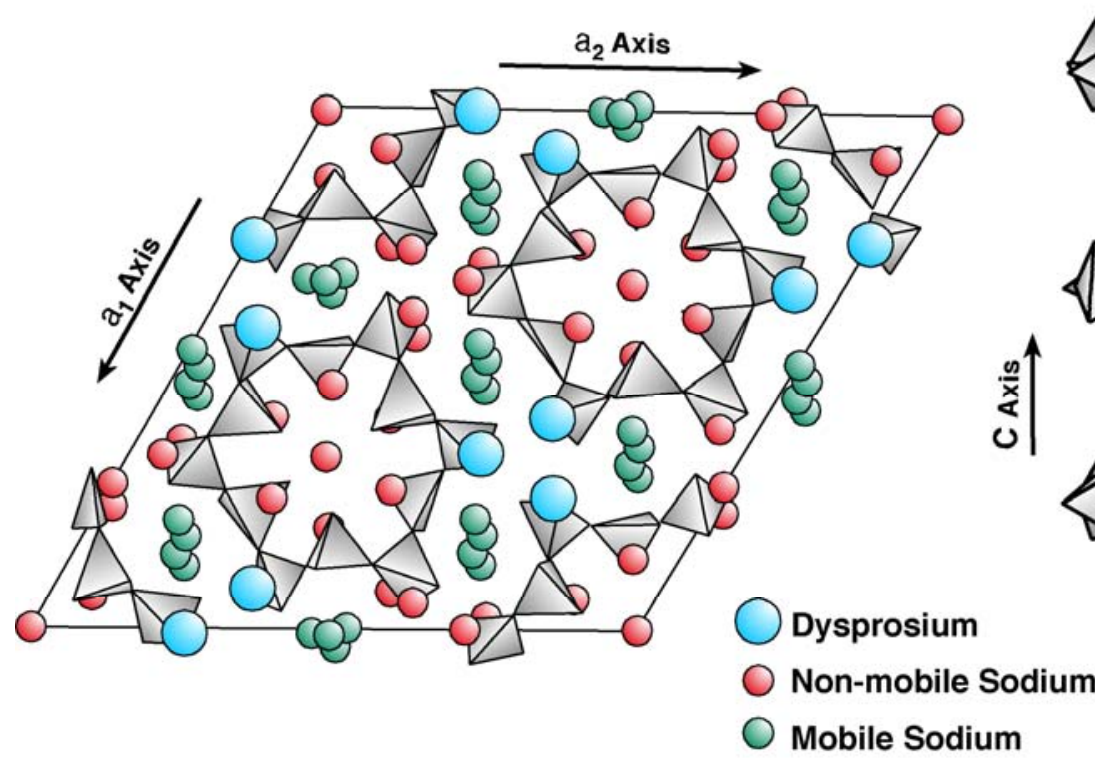

Figure 1.2. RE NaSICON Unit Cell Structure

The ceramics act as Na-selective membranes by sterically restricting the passage of competing ions. Monovalent cations that exhibit some conductivity in these materials are hydronium, $\mathrm{K}+$, and $\mathrm{Ag}+$. Larger monovalent cations such as $\mathrm{Cs}^{+}$tend to be excluded from the crystal lattice by size, although there is some evidence for the transport of small amounts of cesium. Multivalent ions are excluded by electroneutrality requirements and in some cases by steric effects.

Although a number of organic-based ion exchange membranes are available for use in salt-splitting processes (Strathmann 1992), ceramic membranes offer a number of advantages over organic membranes for treating radioactive wastes. Inorganic materials are generally very resistant to radiation damage, and the Dy-NaSICON materials have been exposed to relatively large amounts of radiation $\left(10^{9}\right.$ Rads from a ${ }^{60} \mathrm{Co}$ gamma source) with no detectable impact on performance (Kurath et al. 1997a). Ceramic membranes have superior resistance to fouling because of the tendency to exclude di- and tri-valent cations that can precipitate in organic membranes during salt splitting. Ceramic membranes also appear to have a high selectivity for Na relative to most other waste components (Kurath et al. 1997a). This is especially important in treating radioactive wastes, where it is desirable to minimize the radioactivity in the recycled $\mathrm{Na}$.

\subsection{Materials Development and Testing Strategy}

In the first part of 1996, a preconceptual design for a full-scale electrochemical cell was developed based on the ceramic membranes (Kurath et al. 1997b). These membranes in the form of disks are incorporated into scaffolds for inserting into commercially available plate and frame electrochemical cells. The design used a number of ceramic disks incorporated into a scaffold consisting of high-density polyethylene (HDPE). The membranes in the scaffolds were sealed using o-rings along the radial edge of the ceramic membranes. Several bench-scale units and a pilot-scale unit were designed and fabricated, based on the full-scale design. 
In 1998, a series of membrane materials were developed and tested with the objective of improving the membrane conductivity and lifetime. The materials were screened by determining the $\mathrm{Na}$ ionic conductivity in static (non-flowing) cells using a combination of DC-pulse (current interrupt) and AC impedance techniques. The membrane materials with the greatest $\mathrm{Na}$ ionic conductivity were subjected to long-term testing in single disk electrochemical cells to assess the chemical and electrochemical stability of the materials and to determine the long-term Na transport efficiency. These membrane compositions with the best combination of ionic conductivity and chemical/electrochemical stability were then incorporated into the multi-disk scaffolds for bench and pilot-scale testing.

The primary goals of the current NaSICON salt-splitting testing are to provide information regarding the process performance using non-radioactive simulant and actual radioactive tank wastes. Specific test objectives include the following:

- Determine the selectivity of the membranes for the various waste components relative to sodium. Components of greatest interest include aluminum, potassium, and the radionuclides $\left({ }^{90} \mathrm{Sr},{ }^{99} \mathrm{Tc}\right.$, ${ }^{137} \mathrm{Cs}$, etc.).

- Good membrane selectivity for sodium is important since this increases the efficiency of the process and the purity of the caustic product.

- Determine any changes that occur in the waste composition induced by the oxidizing environment in the anode compartment.

- This information is important for assessing the potential for solids generation and the potential impact on downstream processes.

- Validate AP104/SY101/AZ101 simulant material with actual AP104/SY101/AZ101 tank waste.

- Validating the simulant allows for more exhaustive testing using the non-radioactive simulant without the high experimental costs and safety issues associated with actual waste tests.

This report describes 1) the experimental approach and procedures that were used in electrochemically testing the membranes, 2) the composition of the feeds and the preparation of simulants, and 3 ) test procedures and the results of the testing. 



\subsection{Experimental Apparatus and Procedure}

\subsection{Membrane Fabrication, Composition, and Dimensions}

The NaSICON membranes are prepared using the following steps: powder mixing to verify a uniform composition, isostatic pressing to verify good packing, and sintering. The sintered disks are then finished to the desired thickness by surface grinding. The membranes are then inspected for surface imperfections with dye testing and visual inspection. Finally, the membranes are subjected to a helium leak test to verify hermeticity.

Several different membrane compositions and three different disk sizes have been tested previously (Kurath 1997c). The RE-NaSICON membrane compositions are based on the rare earth elements dysprosium (Dy-NaSICON) and neodymium (Nd-NaSICON). The new family of NaSICON and doped NaSICON compositions that have been tested are denoted NAS-D, NAS-E, NAS-G, and NAS-H where the letters $\mathrm{D}, \mathrm{E}, \mathrm{G}$, and $\mathrm{H}$ denote a given class of compositions. A variable $\mathrm{X}$ is used to denote the concentration of various dopants (e.g., NAS-D 10). These compositions were developed to increase the sodium transport rate by increasing the channel size for sodium ion conduction. The X dopant in the composition provides chemical and electrochemical stability toward corrosion. Membranes were fabricated with diameters of $2.54 \mathrm{~cm}, 3.9 \mathrm{~cm}$, and $5.1 \mathrm{~cm}$ and a thickness that is typically 1.4 to $1.5 \mathrm{~mm}$. Approximately 70 disks (5 $\mathrm{cm}$ [2 in.]) of the NAS-D material were fabricated for the pilot-scale scaffold. Disks as thin as $0.7 \mathrm{~mm}$ have been fabricated and tested in an effort to reduce the resistance of the membranes to ionic conduction and thereby lower the voltage drop across the membrane. Results from this previous work indicate that the NAS-GY membrane material possesses a factor of 4 greater conductivity than NAS-D materials and a superior stability. Further development and refinement by Ceramatec Inc. has generated a 3-inch-diameter NAS-GY (816Y) membrane material as a primary candidate for commercialization, and it is the focus of this research work.

\subsection{Bench-Scale Electrochemical Test System}

Figure 2.1 shows a schematic of the electrochemical flow cell used for simulant and actual waste testing. Separate flow loops were provided for the anolyte and catholyte solutions. Each loop consisted of a solution storage reservoir, pump, and flow-control meter. An inert gas purge line was supplied to the catholyte solution container to prevent the buildup of potentially flammable gases generated in the cathode. A simple ambient air condenser was placed on the cathode outlet line to recover any evaporation losses. The operating temperature was maintained with two $6 \times 12$ inch fiberglass reinforced siliconerubber heat blankets capable of $90 \mathrm{~W}$ outputs and controlled by Omega CN7100 temperature controllers with Omega K-type (Model\# HKQSS-18G-12) thermocouples to provide temperature feedback. Actual reservoir and cell outlet temperatures were monitored manually with a Fluke 54II handheld thermometer and Omega PFA-coated T-type thermocouples (Model\# CPSS-18G-12-PFA).

Power was supplied with a BOSS model 730 electrochemical unit manufactured by the Electrosynthesis Company. Voltage ( 0 to 60 volts) or current ( 0 to 50 amps) could be directly set. All experiments were conducted at a constant current. The BOSS power supply also monitored various experimental parameters and automatically shut down the system if the parameters were exceeded. Voltage and current output signals from the BOSS power supply were recorded with an Agilent 34970A data-acquisition system using a 34901A hardware board and stored on a computer hard disk. 


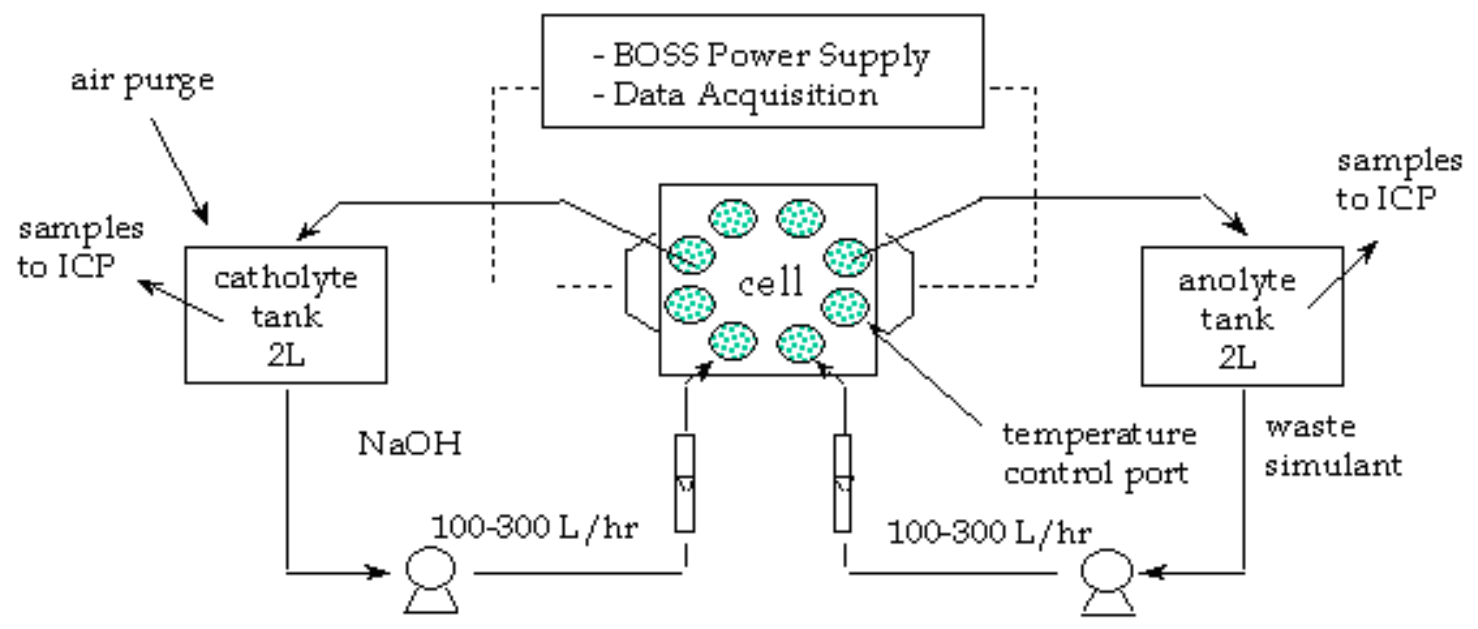

Figure 2.1. Bench-Scale Electrochemical Salt-Splitting System

The anolyte and catholyte reservoirs consisted of polypropylene (PP) tanks with a 2-L capacity. The fittings for the tank are of the Swagelok ${ }^{\mathrm{TM}}$ type. The piping used for both the non-radioactive (simulant testing) and radioactive testing was polytetrafluoroethylene (PTFE) tubing $(7 / 16$-inch ID $\times 1 / 2$-inch OD) with PP fittings. Two caustic-resistant, magnetically driven centrifugal pumps (Little Giant model \# 4-MD-SC) were used to circulate the catholyte and anolyte solutions through their respective loops. Both pumps were rated at $0.1 \mathrm{hp}$. Solution flow rates were monitored and controlled with 4 inch Key Instrument rotameters (Model\# FR4L54SVEPDM) with a flow range of 0 to $180 \mathrm{~L} / \mathrm{h}$ (water basis). Flow rates between from 138 to $156 \mathrm{~L} / \mathrm{h}$ were maintained. Solution loop and transmembrane pressures were monitored with corrosive service gauges capable of 0 to 15 psig and incremental markings of 0.25 psig each.

The electrochemical cell (Figure 2.2) is a modified Electro multi-purpose (MP) model (ElectroCell AB) for bench-scale testing. This is a scaled-down version of a production unit, the Electro Prod Cell (ElectroCell $\mathrm{AB}$ ), which has an electrode area of $4000 \mathrm{~cm}^{2}$. The electrodes were platinized titanium (anode) and nickel (cathode) with a projected surface area of $100 \mathrm{~cm}^{2}$. The cell materials of construction are scaffold-HDPE, flow promoter-PP, gaskets-ethylene-propylene-diene monomer (EPDM) rubber, and metal endplates, bolts-316 stainless steel. Separate flow channels are provided in the cell for circulating cooling/heating water for temperature control, but this feature was not used. Turbulence promoters were inserted between the scaffold and the electrode surface to promote solution mixing. A minimum flow rate of $60 \mathrm{~L} / \mathrm{h}$ is specified by the manufacturer for the MP cell.

The 1.4-mm-thick, 7.62-cm-diameter ceramic membrane, with a NAS-GY formulation, was incorporated as a disk into a scaffold consisting of $0.635-\mathrm{cm}(1 / 4-$ in.) HDPE. The membrane disk was sealed at the edge and offered an active membrane surface area of $45.6 \mathrm{~cm}^{2}$. All testing was completed with the same ceramic disk membrane.

All catholyte solutions were prepared using reagent-grade chemicals and deionized, distilled water (DDI). In the final experiment, a known mass of $19 \mathrm{M} \mathrm{NaOH}$ was added to the anolyte reservoir to replenish the $\mathrm{Na}$ and hydroxide quantities lost in the previous test. 


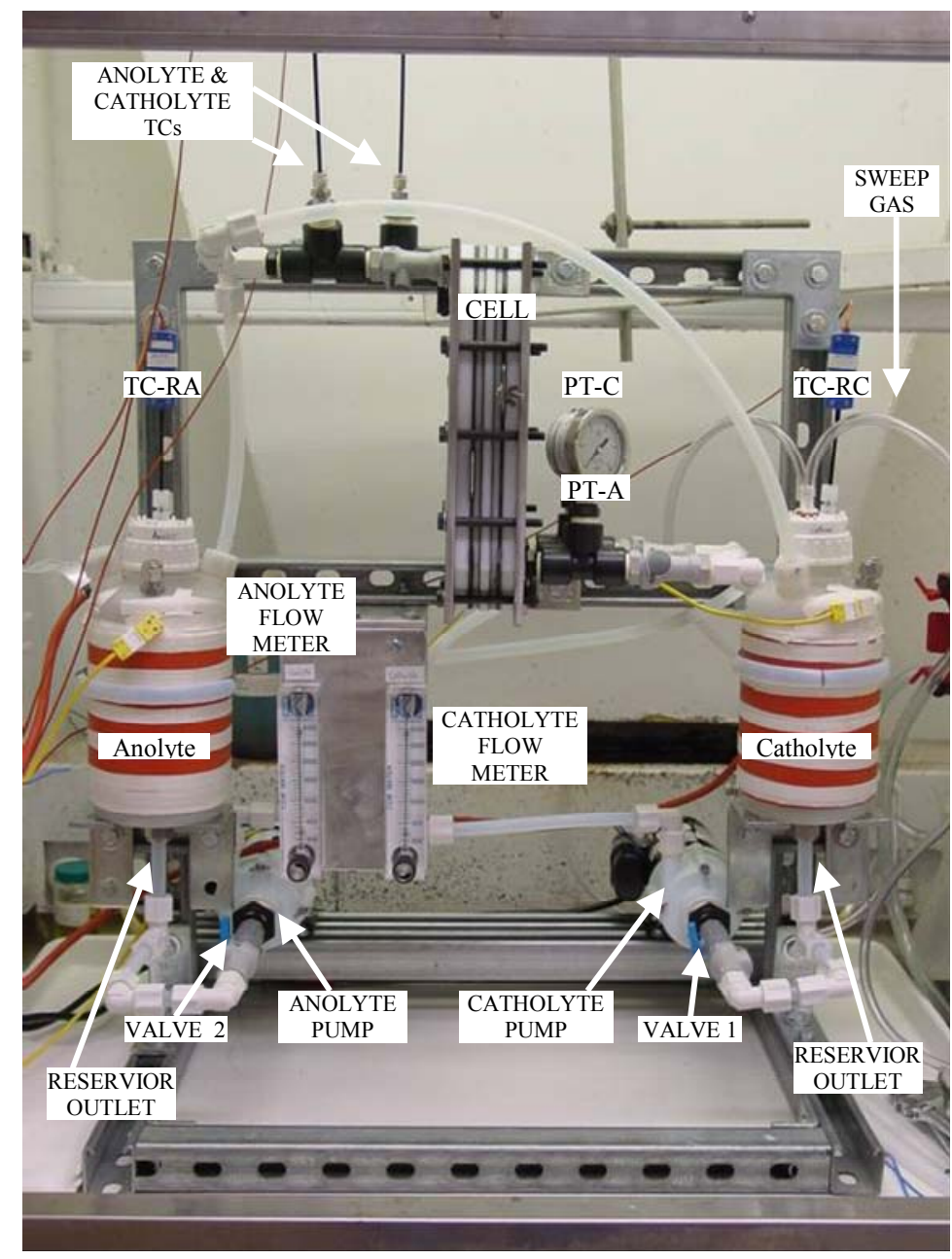

Figure 2.2. Bench-Scale Electrochemical Cell System: Electro MP (Electro Cell AB)

The system was operated in a batch recycle mode with initial feedstock volumes ranging from 0.8 to $1.2 \mathrm{~L}$. The flow rate of the recirculating solutions ranged from 138 to $156 \mathrm{~L} / \mathrm{h}$. In the non-radioactive test and first radioactive test, the initial catholyte solution consisted of $1 \mathrm{M} \mathrm{NaOH}$ to provide conductivity for ionic transport. The final test used $\sim 18.6 \mathrm{M} \mathrm{NaOH}$ as the initial catholyte solution. The anolyte consisted of either AP104/SY101/AZ101 simulant and actual AP104/SY101/AZ101 tank waste.

Sample volumes of 5 to $10 \mathrm{~mL}$ (depending on the analytical requirements) were taken at least every 30 minutes during simulant testing and 45 minutes during radioactive testing. It was beneficial to minimize the sample volume since the larger sample volume removed a substantial amount of $\mathrm{Na}$ from the system over the course of an experiment.

The testing duration was primarily dictated by the start of $\mathrm{Al}(\mathrm{OH})_{3}$ (Gibbsite) precipitation as the anolyte solution $\mathrm{pH}$ approached 12. Solution $\mathrm{pH}$ levels were monitored with Hydrion microfine $\mathrm{pH}$ paper. Experiments with actual wastes were conducted without adding caustic and were terminated when solids started to precipitate. The temperature of the system was normally controlled at $40^{\circ} \mathrm{C}$. 
The process samples were analyzed using inductively coupled plasma-optical emission spectrometry (ICP-OES), which provided concentrations of the important cations. The uncertainty of the ICP-OES measurement is estimated at $\pm 5 \%$ based on both the blank spike and the matrix spike recoveries. Hydroxide analyses were completed using a Brinkman 636 Auto-titrator. Standard recoveries exceeded $97 \%$ and matrix spikes exceeded $92 \%$ recoveries. Sodium mass balances were used to check the consistency of the results and to check for $\mathrm{Na}$ losses due to leaks and weeping around the connections. Selected samples were also analyzed with total organic carbon (organic content), total inorganic carbon (carbonate), ion chromatography (anions), and hydroxyl ion titration to obtain information on the changes in waste chemistry. For the tests with actual waste, gamma energy analysis (GEA) was used to determine the concentrations of ${ }^{60} \mathrm{Co},{ }^{106} \mathrm{Ru} / \mathrm{Rh},{ }^{126} \mathrm{Sn} / \mathrm{Sb},{ }^{137} \mathrm{Cs},{ }^{154} \mathrm{Eu},{ }^{155} \mathrm{Eu}$, and ${ }^{241} \mathrm{Am}$. The ${ }^{99} \mathrm{Tc}$ concentration was determined by liquid scintillation counting after a combination of ion exchange and solvent extraction. The ${ }^{90} \mathrm{Sr}$ concentration was determined using extraction chromatography followed by liquid scintillation counting. The identity of precipitated solids was determined in previous work using electron and X-ray diffraction (XRD) spectroscopy and was not re-identified in this work.

\subsection{Feed Compositions and Simulant Preparation}

Selecting the actual waste feed was constrained by the wastes that were available. The priority was to use a high-caustic, low-cesium treated supernate waste. Two particular tank-waste samples previously treated by ion exchange were located and deemed as representative tank-waste feeds for conducting caustic recycle experiments. One $351 \mathrm{~mL}$ sample contained a mixture of waste from tanks 241 AP104/SY101 and the other $676 \mathrm{~mL}$ sample contained waste from tank 241-AZ101. (The 241 prefix, common to all Hanford tanks, will not be used hereafter). Both samples had previously been depleted of ${ }^{137} \mathrm{Cs}$ and ${ }^{99} \mathrm{Tc}$ by ion exchange and were combined to produce a composite waste feedstock. Using analytical testing results reported in published internal PNNL reports, Table 2.1 identifies the estimated constituent concentrations in the composited sample. Take note that $\mathrm{Cs}$ and $\mathrm{Sr}$ concentrations were below detection limits for the ICP-OES analysis method and reported as zero. However, Cs, Sr, and other radionuclides were present in the waste sample. Radionuclide concentrations, as determined with GEA analysis, are provided and discussed in Section 4. A photo of the waste material is provided in Figure 2.3.

A simulant recipe was produced during this work to mirror the non-radioactive components identified in the AP104/SY101/AZ101 composited sample. Table 2.2 identifies the estimated constituent concentrations in the simulant. A photo of the simulant material is provided in Figure 2.4.

Table 2.1. AP104/SY101/AZ101 Tank Waste Initial Composition

\begin{tabular}{cr}
\hline Constituent & $\mu \mathrm{g} / \mathrm{mL}$ \\
\hline $\mathrm{Al}$ & 7047 \\
$\mathrm{As}$ & 11 \\
$\mathrm{~B}$ & 19 \\
$\mathrm{Ba}$ & 0 \\
$\mathrm{Ca}$ & 30 \\
$\mathrm{Cd}$ & 2 \\
$\mathrm{Cr}$ & 511 \\
\hline
\end{tabular}

\begin{tabular}{cr}
\hline Constituent & $\mu \mathrm{g} / \mathrm{mL}$ \\
\hline $\mathrm{Sn}$ & 34 \\
$\mathrm{Sr}$ & 0 \\
$\mathrm{Ti}$ & 2 \\
$\mathrm{~V}$ & 1 \\
$\mathrm{~W}$ & 57 \\
$\mathrm{Zn}$ & 2 \\
$\mathrm{Zr}$ & 2 \\
\hline
\end{tabular}


Table 2.1. (contd)

\begin{tabular}{ccccr}
\hline Constituent & $\mu \mathrm{g} / \mathrm{mL}$ & & Constituent & $\mu \mathrm{g} / \mathrm{mL}$ \\
\cline { 1 - 2 } \cline { 5 - 5 } $\mathrm{Cs}$ & 0 & & $\mathrm{U}$ & 0 \\
$\mathrm{Fe}$ & 1 & & $\mathrm{Cl}$ & 1610 \\
$\mathrm{Hg}$ & 1 & & $\mathrm{CO}_{3}$ as Carbon & 5555 \\
$\mathrm{~K}$ & 3079 & & $\mathrm{~F}$ & 1842 \\
$\mathrm{Li}$ & 1 & & $\mathrm{NO}_{2}$ & 59815 \\
$\mathrm{Mo}$ & 73 & & $\mathrm{NO}_{3}$ & 66399 \\
$\mathrm{Na}$ & 104810 & & $\mathrm{OH}_{n}$ & 14241 \\
$\mathrm{Ni}$ & 10 & & $\mathrm{PO}_{4}$ & 2297 \\
$\mathrm{Nd}$ & 3 & & $\mathrm{SO}_{4}$ & 11661 \\
$\mathrm{P}$ & 779 & & Oxalate & 871 \\
$\mathrm{~Pb}$ & 7 & & Acetate & 544 \\
$\mathrm{Pd}$ & 13 & & Citrate & 0 \\
$\mathrm{Rh}$ & 7 & & Formate & 2465 \\
$\mathrm{Ru}$ & 34 & & Gluconate & 0 \\
$\mathrm{Se}$ & 6 & & Glycolate & 0 \\
$\mathrm{Si}$ & 54 & & \\
\hline Concentrations less than 0.5 were rounded to zero & \\
\hline
\end{tabular}

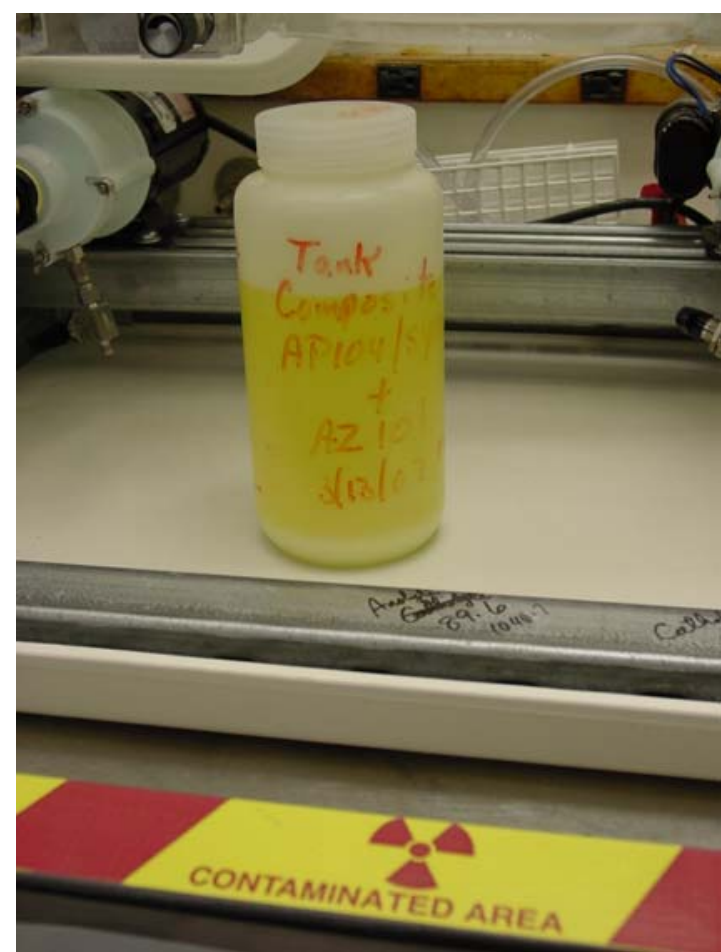

Figure 2.3. Picture of AP104/SY101/AZ101 Tank Waste Sample 
Table 2.2. AP104/SY101/AZ101 Simulant Initial Composition

\begin{tabular}{|c|c|c|c|}
\hline Constituent & $\mu \mathrm{g} / \mathrm{mL}$ & Constituent & $\mu \mathrm{g} / \mathrm{mL}$ \\
\hline $\mathrm{Al}$ & 7277 & Sn & - \\
\hline As & - & $\mathrm{Sr}$ & - \\
\hline B & 19 & $\mathrm{Ti}$ & - \\
\hline $\mathrm{Ba}$ & 4 & V & - \\
\hline $\mathrm{Ca}$ & 32 & W & - \\
\hline $\mathrm{Cd}$ & 4 & $\mathrm{Zn}$ & 2 \\
\hline $\mathrm{Cr}$ & 542 & $\mathrm{Zr}$ & - \\
\hline Cs & - & $\mathrm{U}$ & - \\
\hline $\mathrm{Fe}$ & 1 & $\mathrm{Cl}$ & 1781 \\
\hline $\mathrm{Hg}$ & - & TIC & 25813 \\
\hline K & 3151 & TOC & 11362 \\
\hline $\mathrm{Li}$ & 1 & $\mathrm{~F}$ & 1877 \\
\hline Mo & 69 & $\mathrm{NO} 2$ & 55213 \\
\hline $\mathrm{Na}$ & 107425 & NO3 & 61584 \\
\hline $\mathrm{Ni}$ & 10 & $\mathrm{OH}$ & 14318 \\
\hline $\mathrm{Nd}$ & - & PO4 & 2449 \\
\hline $\mathrm{P}$ & 799 & $\mathrm{SO} 4$ & 12096 \\
\hline $\mathrm{Pb}$ & 29 & oxalate & 1384 \\
\hline $\mathrm{Pd}$ & - & acetate & 560 \\
\hline $\mathrm{Rh}$ & - & citrate & - \\
\hline $\mathrm{Ru}$ & - & formate & 3865 \\
\hline $\mathrm{Se}$ & - & gluconate & - \\
\hline $\mathrm{Si}$ & 56 & glycolate & - \\
\hline \multicolumn{4}{|c|}{$\begin{array}{l}\text { No material was added to simulant for elements with "_" } \\
\text { TIC = Total Inorganic Carbon (calculated from recipe) } \\
\text { TOC = Total Organic Carbon (calculated from recine) }\end{array}$} \\
\hline
\end{tabular}

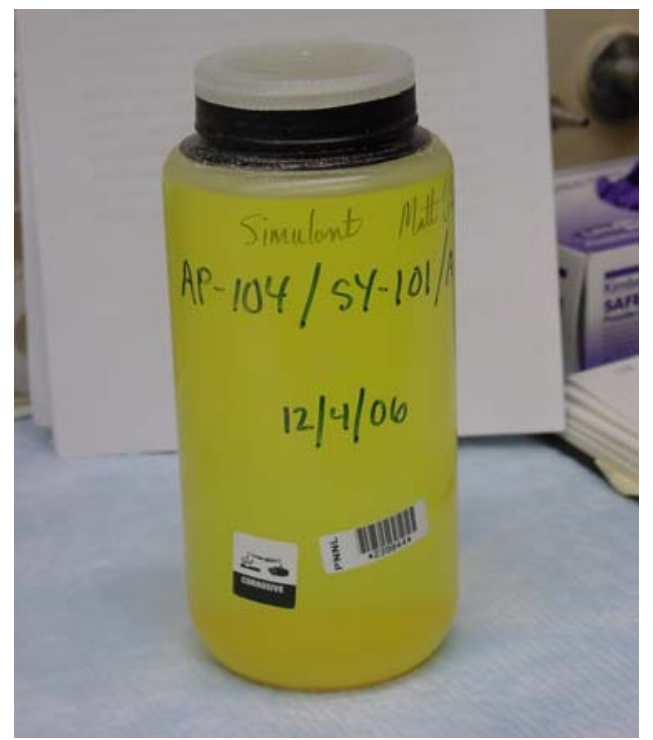

Figure 2.4. Picture of AP104/SY101/AZ104 Waste Simulant 
Ceramatec Inc. prepared the simulant based on the recipe provided by PNNL. Four liters were supplied in four $1 \mathrm{~L}$ Nalgene bottles. Some solid precipitates formed after the original receipt. The simulant was subsequently filtered with a $1 \mu \mathrm{m}$ filter flask prior to experimental use. An analysis of the precipitate was not completed by PNNL. 



\subsection{Experimental Results}

The results of the membrane testing are presented in this section. The results are presented in order of testing with the results for the simulant feed presented first followed by the results of the radioactive testing.

\subsection{Bench-Scale Testing of NAS-GY Single Disk}

Three experiments using a single NAS-GY (876GY) disk $(1.4 \mathrm{~mm}$ thick $\times 7.62 \mathrm{~cm}$ in diameter) were completed using the ElectroCell MP system described previously. The cell was operated in the batch mode, at $40^{\circ} \mathrm{C}$, with no material additions during testing. The current density is based on the exposed membrane area, equal to $45.6 \mathrm{~cm}^{2}$ and fixed at $50 \mathrm{~mA} / \mathrm{cm}^{2}$. Only periodic sampling was performed. Current, temperature, flow rate, and voltage were monitored and recorded throughout the experiment.

Key membrane performance parameters include the sodium-transport efficiency, sodium-transfer rate, and membrane selectivity. The sodium-transport efficiency was determined at various times during the experiment based on chemical analysis of samples. The sodium-transport efficiency, provided in Equation 3.1, is defined as the moles of sodium transported through the membrane relative to the total moles of electrons.

$$
\text { Na Transport Efficiency }=\frac{\text { actual moles of Na transferred }}{I \times t / F}
$$

Current, time, and Faraday's constant (96,484 amp-s/mol) are represented by I, t, and F, respectively. The sodium-transfer rate was determined through chemical analysis of each sample and then averaged over the length of the experiment. Finally, membrane selectivity for $\mathrm{Na}^{+}$over other metal cations is represented by Equation 3.2:

$$
\text { Membrane Selectivity }=\frac{(\text { moles of Na Transferred/Initial Na Concentration })}{(\text { moles of Metal Transferred/Initial Metal Concentration })}
$$

where the moles of materials transferred are based on the catholyte while initial concentrations are based on anolyte analyses.

\subsubsection{Simulant Testing}

Simulant testing was completed before conducting radioactive testing. An AP104/SY101/AZ101 simulant charge of $1206.8 \mathrm{~g}(\sim 1 \mathrm{~L})$ was placed into the anolyte reservoir and $1026.8 \mathrm{~g}(\sim 1 \mathrm{~L})$ of $1 \mathrm{M}$ $\mathrm{NaOH}$ was charged to the catholyte reservoir. Experimental conditions are provided in Table 3.1.

Figure 3.1 displays current density and applied voltage over the course of the experiment. The current density remained relatively steady, increasing only slightly from $50.90 \mathrm{~mA} / \mathrm{cm}^{2}$ to $51.03 \mathrm{~mA} / \mathrm{cm}^{2}$ while the voltage initially rose from $3.97 \mathrm{~V}$ at 2 minutes to a maximum voltage of 4.10 at 33.7 minutes before decreasing over time to a final voltage of $3.88 \mathrm{~V}$ at 302 minutes. No solids precipitation was observed, and testing was stopped just before reaching $\mathrm{pH} 13.6$ in the anolyte. 
Table 3.1. Summary of Simulant Testing Experimental Conditions

\begin{tabular}{ll}
\hline \multicolumn{1}{c}{ Experimental Parameter } & \multicolumn{1}{c}{ Value or Range } \\
\hline Membrane Type & NAS-GY $(876 \mathrm{GY})$ \\
Membrane Thickness & $1.4 \mathrm{~mm}$ \\
Membrane Diameter & $7.62 \mathrm{~cm}$ \\
Current Density & $50-51 \mathrm{~mA} / \mathrm{cm}^{2}$ \\
Applied Current (Min-Max) & $2.32-2.33 \mathrm{amps}$ \\
Applied Voltage (Min-Max) & $3.86-4.10$ volts \\
Temperature & $39-41^{\circ} \mathrm{C}$ \\
Active Membrane Area & $45.6 \mathrm{~cm}^{2}$ \\
Anolyte Flow Rate & $2.3-2.4 \mathrm{~L} / \mathrm{min}$ \\
Catholyte Flow Rate & $2.5-2.6 \mathrm{~L} / \mathrm{min}$ \\
Scaffold Configuration & edge seal \\
Catholyte & $1 \mathrm{M} \mathrm{NaOH}$ \\
Transmembrane $\Delta \mathrm{P}$ & $\leq 0.25 \mathrm{psig}$ \\
Flow Channel $\Delta \mathrm{P}$ & $1.5-1.75 \mathrm{psig}$ \\
\hline
\end{tabular}

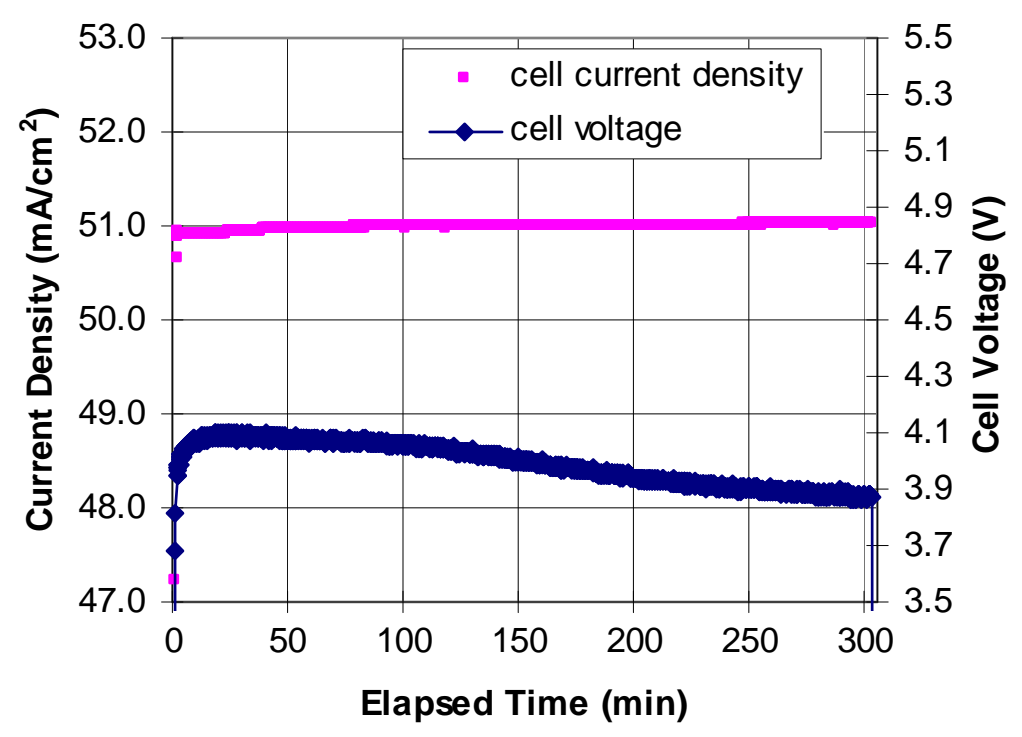

Figure 3.1. Voltage and Current Density During Simulant Testing

Figure 3.2 illustrates a good agreement between theoretical and the actual sodium transport rate. The theoretical transport rate assumes that all applied current was involved in electron transfer. Aside from a slight offset, the slopes of the lines are approximately equal.

The sodium transport efficiency was determined through $\mathrm{OH}^{-}$titration results on the catholyte samples. $\mathrm{OH}^{-}$titration standard recovery was $107 \%$ while matrix spikes were 95 to $96 \%$. The first sample, at 62 minutes, was low at $88 \%$ while the next three samples produced 93 to $95 \%$ efficiencies. The average efficiency was $93 \%$. The average sodium transfer rate was $9.6 \mathrm{~kg} / \mathrm{day} / \mathrm{m}^{2}$. For the simulant test, the samples were only analyzed by $\mathrm{OH}^{-}$titration. 


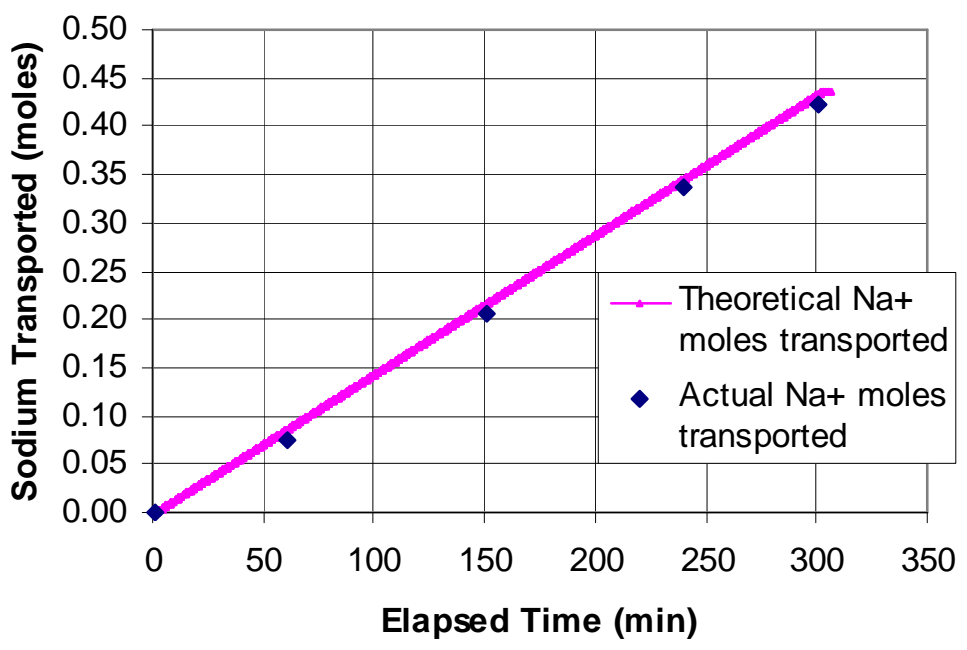

Figure 3.2. Sodium Transport Rate Comparison During Simulant Testing

\subsubsection{AP104/SY101/AZ101 Radioactive Anolyte Test \#1 (1 M NaOH Catholyte)}

Treatment of the radioactive AP104/SY101/AZ101 tank waste sample was completed after a successful simulant test. The caustic-recycle-system apparatus was moved from a non-radiological hood into a radiological hood within the same laboratory. No system breach or other modifications were performed. An $1121.5 \mathrm{~g}(\sim 912 \mathrm{~mL})$ sample of AP104/SY101/AZ101 tank waste was charged to the anolyte reservoir, and $1028.1 \mathrm{~g}(\sim 993 \mathrm{~mL})$ of $1 \mathrm{M} \mathrm{NaOH}$ was charged to the catholyte reservoir. Experimental conditions are provided in Table 3.2.

Table 3.2. Summary of Radioactive Test \#1 (1 M NaOH Catholyte) Experimental Conditions

\begin{tabular}{ll}
\hline Experimental Parameter & Value or Range \\
\hline Membrane Type & NAS-GY $(876 \mathrm{GY})$ \\
Membrane Thickness & $1.4 \mathrm{~mm}$ \\
Membrane Diameter & $7.62 \mathrm{~cm}$ \\
Current Density & $50 \mathrm{~mA} / \mathrm{cm}^{2}$ \\
Applied Current (Min-Max) & $2.24-2.29 \mathrm{amps}$ \\
Applied Voltage (Min-Max) & $4.12-4.62 \mathrm{volts}$ \\
Temperature & $37-42^{\circ} \mathrm{C}$ \\
Active Membrane Area & $45.6 \mathrm{~cm}^{2}$ \\
Anolyte Flow Rate & $2.4-2.5 \mathrm{~L} / \mathrm{min}$ \\
Catholyte Flow Rate & $2.5-2.7 \mathrm{~L} / \mathrm{min}$ \\
Scaffold Configuration & edge seal \\
Catholyte & $1 \mathrm{M} \mathrm{NaOH}$ \\
Transmembrane $\Delta \mathrm{P}$ & $\leq 0.25 \mathrm{psig}$ \\
Flow Channel $\Delta \mathrm{P}$ & $1.6-1.8 \mathrm{psig}$ \\
\hline
\end{tabular}


Figure 3.3 displays current density and applied voltage over the course of the experiment. The current density remained steady while voltage remained flat initially until around 100 minutes. The voltage steadily increased after 100 minutes until roughly 220 minutes where the voltage appears to slightly decrease before again resuming a steady increase in voltage until 390 minutes. At roughly 390 minutes, a significant increase in the rate of voltage rise was observed. The $\mathrm{pH}$ indicator strips, with $0.3-\mathrm{pH}$ resolution, indicated a $\mathrm{pH}$ of approximately 13.2. A sharp change in current density can be observed at approximately 397 minutes. Due to operator error, the electrochemical unit became voltage controlled, and the upper voltage limit was increased to allow the equipment to remain in current controlled mode. The experiment was ended at the first visual indication of solids precipitation, and a final sample was taken.

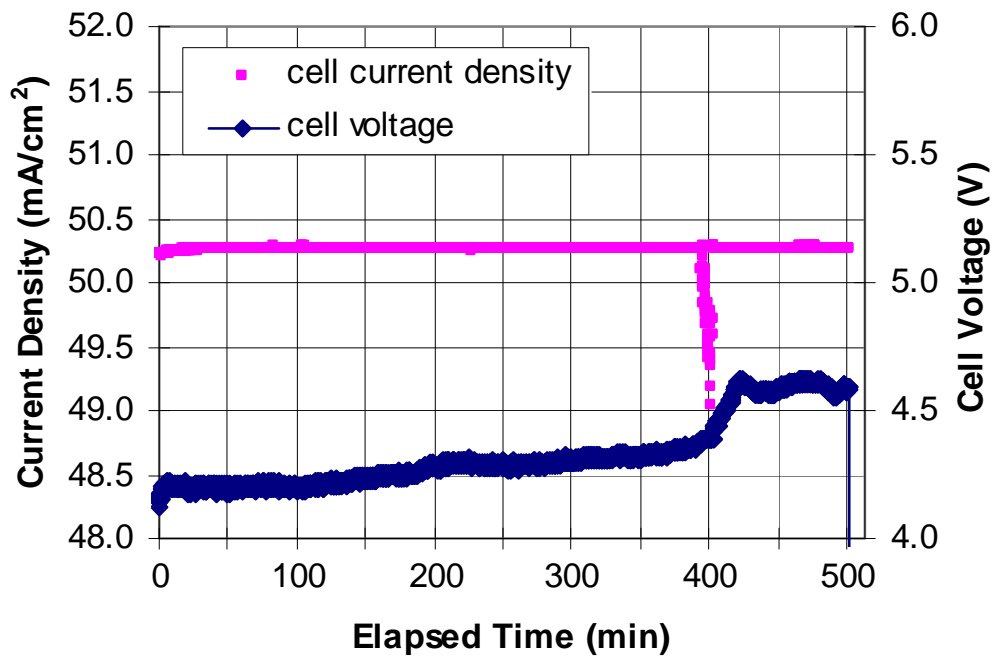

Figure 3.3. Voltage and Current Density during Radioactive Test \#1 (1 M NaOH Catholyte)

Samples were obtained at least every 45 minutes from both the catholyte and anolyte. These samples were then submitted for analytical analyses, which included OH titration, ICP-OES (cations), ion chromatography (IC) (anions), total inorganic carbon (TIC) and total organic carbon (TOC) analysis by a hot persulfate wet oxidation method, radionuclide identification by Gamma Energy Analysis (GEA), and total alpha and beta activity by liquid scintillation.

Using $\mathrm{OH}^{-}$titration data from the catholyte samples, Figure 3.4 illustrates good agreement between theoretical and the actual sodium transport rate.

The sodium-transport efficiency was determined through $\mathrm{OH}^{-}$titration results on the catholyte samples. Efficiencies varied from 94 to $101 \%$ over the course of the experiment while the average efficiency was $99 \%$. The average sodium transfer rate was $10.3 \mathrm{~kg} /$ day $/ \mathrm{m}^{2}$. Based on ICP-OES analysis of the catholyte, no discernable transport of non-Na cations was observed. GEA indicated that about $0.04 \%$ of the initial ${ }^{137} \mathrm{Cs}$ in the anolyte was transported to the catholyte. No other radionuclides were transported and measured in the catholyte solution above detection limits. The sodium selectivity with respect to ${ }^{137} \mathrm{Cs}$ was 384 . 


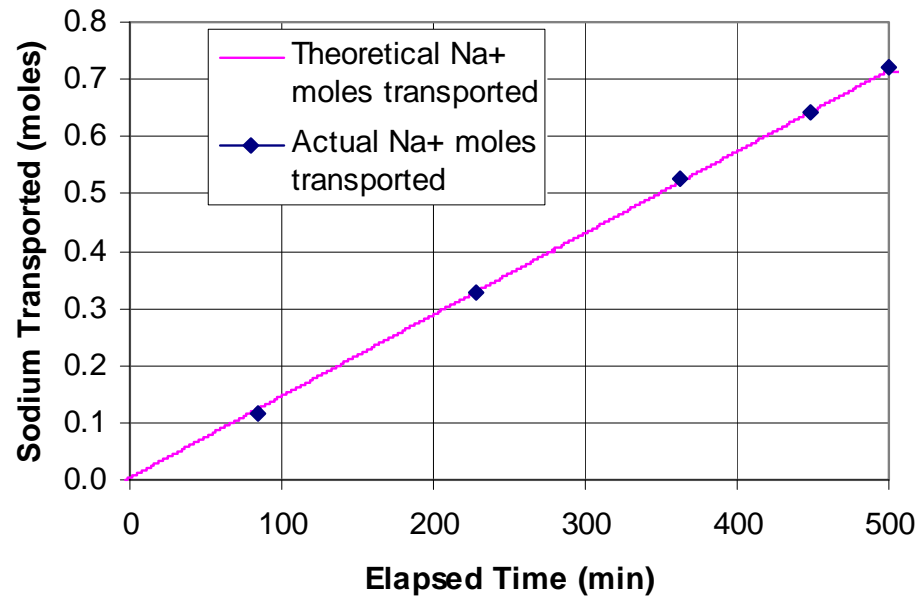

Figure 3.4. Sodium Transport Rate Comparison during Radioactive Test \#1 (1 M NaOH Catholyte)

\subsubsection{AP104/SY101/AZ101 Radioactive Anolyte Test \#2 (18.6 M NaOH catholyte)}

A second radioactive test was completed using the sodium-depleted anolyte solution from the previous (Rad Test \#1) experiment. To replenish the anolyte reservoir of depleted sodium hydroxide, a $52.9 \mathrm{~g}$ addition of $19 \mathrm{M} \mathrm{NaOH}$ was made at the end of the previous day's test. The anolyte solution was recirculated through the anolyte loop for 7 minutes to re-dissolve the precipitate into solution before shutting down. The catholyte solution was drained from the previous experiment (Rad Test \#1) and replaced with $1502 \mathrm{~g}(\sim 984 \mathrm{~mL})$ of $19 \mathrm{M} \mathrm{NaOH}$. Based on previous volume-recovery measurements of catholyte solutions and the measured catholyte concentration $(1.75 \mathrm{M} \mathrm{NaOH})$, the new concentration of the catholyte feedstock solution was estimated to be $18.6 \mathrm{M} \mathrm{NaOH}$. Experimental conditions are provided in Table 3.3 .

Table 3.3. Summary of Radioactive Test \#2 (18.6 M NaOH Catholyte) Experimental Conditions

\begin{tabular}{ll}
\hline Experimental Parameter & Value or Range \\
\hline Membrane Type & NAS-GY (876 GY) \\
Membrane Thickness & $1.4 \mathrm{~mm}$ \\
Membrane Diameter & $7.62 \mathrm{~cm}$ \\
Current Density & $50 \mathrm{~mA} / \mathrm{cm}^{2}$ \\
Applied Current (Min-Max) & $2.29 \mathrm{amps}$ \\
Applied Voltage (Min-Max) & $4.36-5.44$ volts \\
Temperature & $41-43^{\circ} \mathrm{C}$ \\
Active Membrane Area & $45.6 \mathrm{~cm}^{2}$ \\
Anolyte Flow Rate & $2.4-2.5 \mathrm{~L} / \mathrm{min}$ \\
Catholyte Flow Rate & $1.7-1.9 \mathrm{~L} / \mathrm{min}$ \\
Scaffold Configuration & edge seal \\
Catholyte & $18.6 \mathrm{M} \mathrm{NaOH}$ \\
Transmembrane $\Delta \mathrm{P}$ & $\leq 0.25 \mathrm{psig}$ \\
Flow Channel $\Delta \mathrm{P}$ & $1.9 \mathrm{psig}$ \\
\hline
\end{tabular}


Figure 3.5 displays current density and applied voltage over the course of the experiment. The current density was again steady over the experiment while the voltage had a short period of level voltage ( 0 to 20 minutes) followed by a steady rate of voltage increase until approximately 100 minutes. At 335 minutes, a sharp increase in voltage was recorded and continued until roughly 375 minutes when the voltage started approaching a level value. Precipitated/suspended solids were observed immediately in the anolyte sample obtained at 438 minutes. The experiment was ended at the first visual indication of solids precipitation, and a final sample was taken. It should be also noted that precipitated/suspended solids were also identified, 3 days later, in a sample collected at 427 minutes while preparing to submit analytical samples.

Samples were obtained at least every 45 minutes for both the catholyte and anolyte. These samples were then submitted for analytical analyses, which included OH titration, ICP-OES (cations), ion chromatography (IC) (anions), total inorganic carbon (TIC) and total organic carbon (TOC) analysis by a hot persulfate wet oxidation method, radionuclide identification by Gamma Energy Analysis (GEA), and total alpha and beta activity by liquid scintillation.

Due to large analytical errors produced during dilutions for $\mathrm{OH}^{-}$titration analysis on $\sim 19 \mathrm{M} \mathrm{NaOH}$ catholyte samples, anolyte $\mathrm{OH}^{-}$titration data were used to produce performance results in the second radiological test. Figure 3.6 illustrates good agreement between theoretical and the actual sodium transport rates.

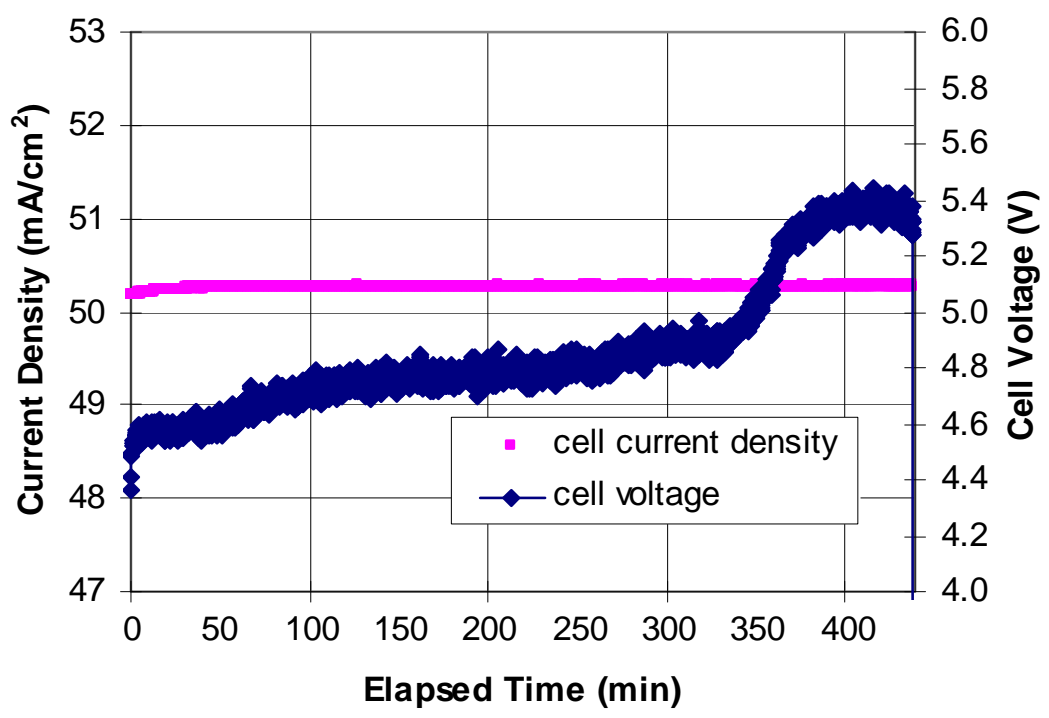

Figure 3.5. Voltage and Current Density during Radioactive Test \#2 (18.6 M NaOH Catholyte)

The sodium-transport efficiency was determined through $\mathrm{OH}^{-}$titration results on the anolyte samples. Efficiencies varied from 95 to $102 \%$ over the course of the experiment while the average efficiency was $99 \%$. The average sodium transfer rate was $10.3 \mathrm{~kg} /$ day $/ \mathrm{m}^{2}$. Based on ICP-OES analysis of the catholyte, no discernable transport of non-Na cations was observed. GEA indicated that about $0.06 \%$ of the initial ${ }^{137} \mathrm{Cs}$ in the anolyte was transported to the catholyte. No other radionuclides were transported and measured in the catholyte solution above detection limits. The sodium selectivity with respect to ${ }^{137} \mathrm{Cs}$ was 250 . 


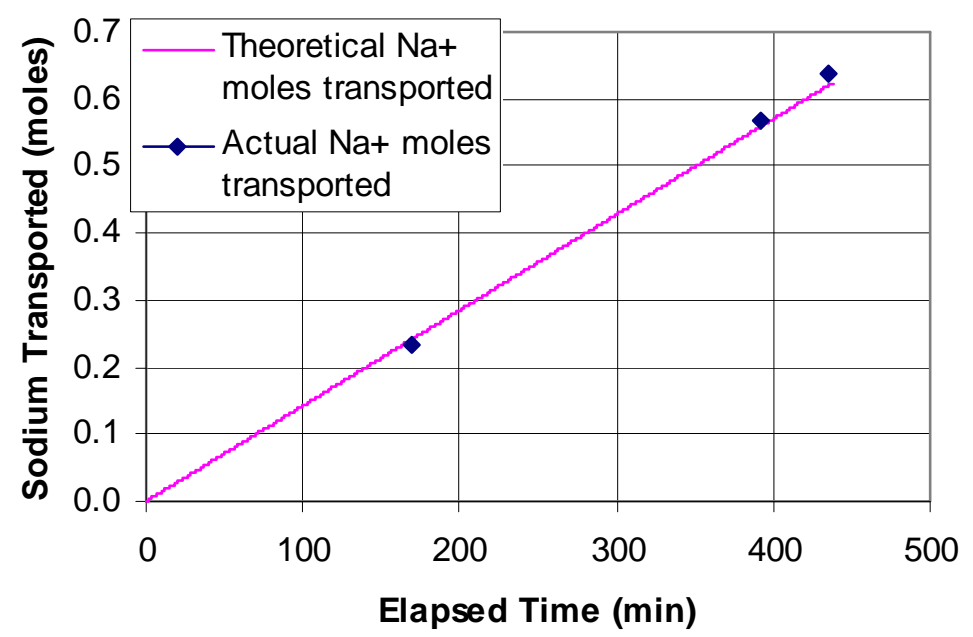

Figure 3.6. Sodium Transport Rate Comparison during Radioactive Test \#2 (18.6 M NaOH Catholyte) 



\subsection{Results Discussion}

The primary goals of the current NaSICON salt-splitting testing were to obtain process performance results using actual radioactive tank waste and a non-radiological simulant. The objectives of the tests performed were to:

- Determine Na transfer rates.

- Determine Na transfer efficiencies.

- Determine membrane selectivity for the various waste components relative to sodium. Components of greatest interest include aluminum, potassium, and the radionuclides $\left({ }^{90} \mathrm{Sr},{ }^{99} \mathrm{Tc}\right.$, and $\left.{ }^{137} \mathrm{Cs}\right)$.

- Verify the results of simulant testing with actual waste.

- Determine any of the changes that occur in the waste composition induced by the oxidizing environment in the anode compartment.

- $\quad$ Test o-ring and membrane integrity.

A summary of process parameters for the three experiments is provided in Table 4.1. With few exceptions, little variation in operating conditions existed between experiments. A change in flowrate was seen in radiological test $\# 2$ due to the increased density and viscosity of the high molarity $\mathrm{NaOH}$ solution. No detrimental effect was expected since the minimum specified manufacturer flowrates $(1 \mathrm{~L} / \mathrm{min})$ were exceeded. The most notable difference was the change in cell voltage for each experiment. This is discussed further in the following paragraphs.

Cell voltage changes were monitored over time, and the rate of these changes varied from test to test. Figure 4.1 illustrates the cumulative changes in the voltage and current-density changes over time for the three tests performed. These results were consistent with previous results obtained by Hobbs (1999) where a significant increase in voltage is observed in the latter stages of testing. However, Hobbs (1999) concluded the voltage increase occurred from an anodic reaction shift from hydroxide and nitrite oxidation to water oxidation as the former species became depleted. This conclusion is not supported in this work since approximately $70 \%$ of the original nitrite concentration in the anolyte remains at the conclusion of each test. Other possible contributions to the voltage increases include the effects of solids precipitation, material plating on the electrodes or membrane surfaces, a solution conductivity decrease, or changes in the crystal structure of the membrane.

During simulant testing, a slight decrease in voltage is observed over the course of the experiment. This behavior has been observed previously by Ceramatec Inc. and believed to be due to a change in the impedance at the membrane-anolyte and catholyte interface.

The voltage jump from $3.9 \mathrm{~V}$ to $4.1 \mathrm{~V}$ between the end of the simulant testing and the start of the first radiological test is believed to result from a change in anolyte solutions and/or some degradation during a 2-week exposure to the DI rinse after the simulant experiment. 
Table 4.1. Summary of Process Parameters for All Experiments

\begin{tabular}{|c|c|c|c|}
\hline \multirow{2}{*}{ Operational Parameter } & \multicolumn{3}{|c|}{ Test ID } \\
\hline & Simulant & RAD Test \#1 & RAD Test \#2 \\
\hline Membrane Type & NAS-GY (876 GY) & NAS-GY (876 GY) & NAS-GY (876 GY) \\
\hline Membrane Thickness (mm) & 1.4 & 1.4 & 1.4 \\
\hline Membrane Diameter (cm) & 7.62 & 7.62 & 7.62 \\
\hline Current Density $\left(\mathrm{mA} / \mathrm{cm}^{2}\right)$ & 51 & 50 & 50 \\
\hline Applied Current (min-max amps) & $2.32-2.33$ & $2.24-2.29$ & 2.29 \\
\hline Applied Current (min-max volts) & $3.86-4.10$ & $4.12-4.62$ & $4.36-5.44$ \\
\hline Temperature $\left({ }^{\circ} \mathrm{C}\right)$ & $39-41$ & $37-43$ & $41-43$ \\
\hline Active Membrane Area $\left(\mathrm{cm}^{2}\right)$ & 45.6 & 45.6 & 45.6 \\
\hline Anolyte Flow Rate (L/min) & $2.3-2.4$ & $2.4-2.5$ & $2.4-2.5$ \\
\hline Catholyte Flow Rate (L/min) & $2.5-2.6$ & $2.5-2.7$ & $1.7-.9$ \\
\hline Catholyte (M NaOH) & 1 & 1 & 18.6 \\
\hline Operating DP (psig) & $1.5-1.75$ & $1.6-1.9$ & 1.9 \\
\hline Na Transport Efficiency (\%) & $88-95$ & $95-101$ & $95-02$ \\
\hline $\mathrm{Na}$ Transport Rate $\left(\mathrm{kg} / \mathrm{day} / \mathrm{m}^{2}\right)$ & 9.6 & 10.3 & 10.3 \\
\hline Operating Time (h) & 5 & 8.2 & 7.3 \\
\hline
\end{tabular}

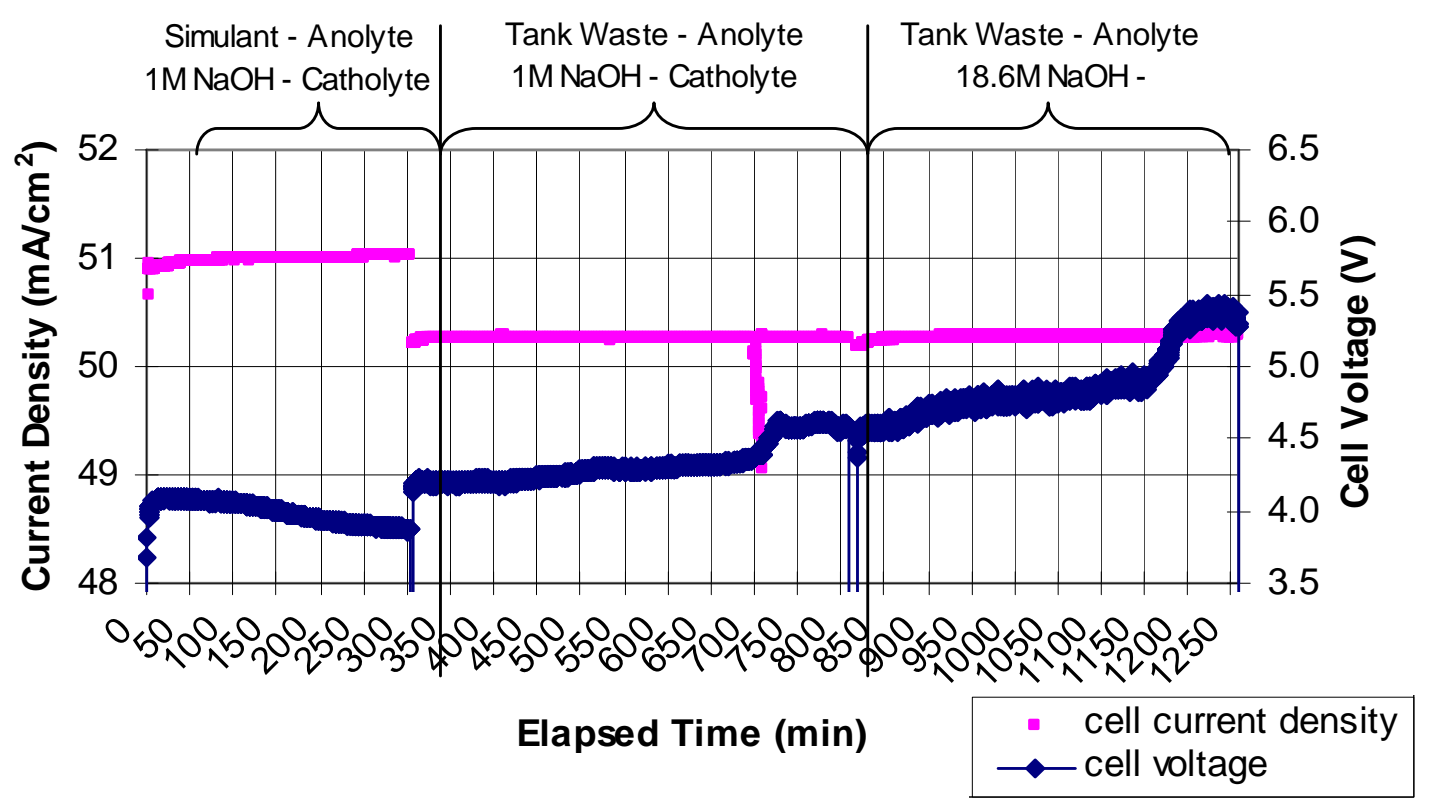

Figure 4.1. Current Density and Voltage Behavior over Three Test Case History 
A clear change in voltage was observed at 750 minutes (cf. in Figure 4.1) during radiological test \#1 and 1200 minutes (cf. Figure 4.1) during radiological test \#2. It is assumed that this behavior is due to the increased cell resistance caused by the precipitation of aluminate in the form of gibbsite in the anolyte chamber and on the electrode or membrane surface. Analytical ICP-OES data of the anolyte samples taken shows a steady $\mathrm{Al}$ concentration in the anolyte until a sharp decrease occurs after the abovementioned voltage increases. These results support a well documented observation that dissolved aluminate will precipitate out of solution as the $\mathrm{pH}$ decreases below 13.6 when the equilibrium aluminate solubility in $\mathrm{NaOH}$ is surpassed (Misra 1970). Surface studies of the membrane have not been completed at this time and could provide insight into this voltage change.

A relatively low initial $\mathrm{Na}$ current efficiency during simulant testing was noted. An initial unsaturated membrane is a possible explanation for this behavior and supports observations made previously by Ceramatec. It was also noted and illustrated in Figure 4.2 that the initial differential transport efficiency in all three experiments was slightly lower than subsequent efficiency results in the middle and late periods of testing. Capacitive charging currents at the electrodes or membrane surface are believed to be a possible cause of the low current efficiencies during the initial testing periods. Alternative electrode reactions are also a possible explanation.

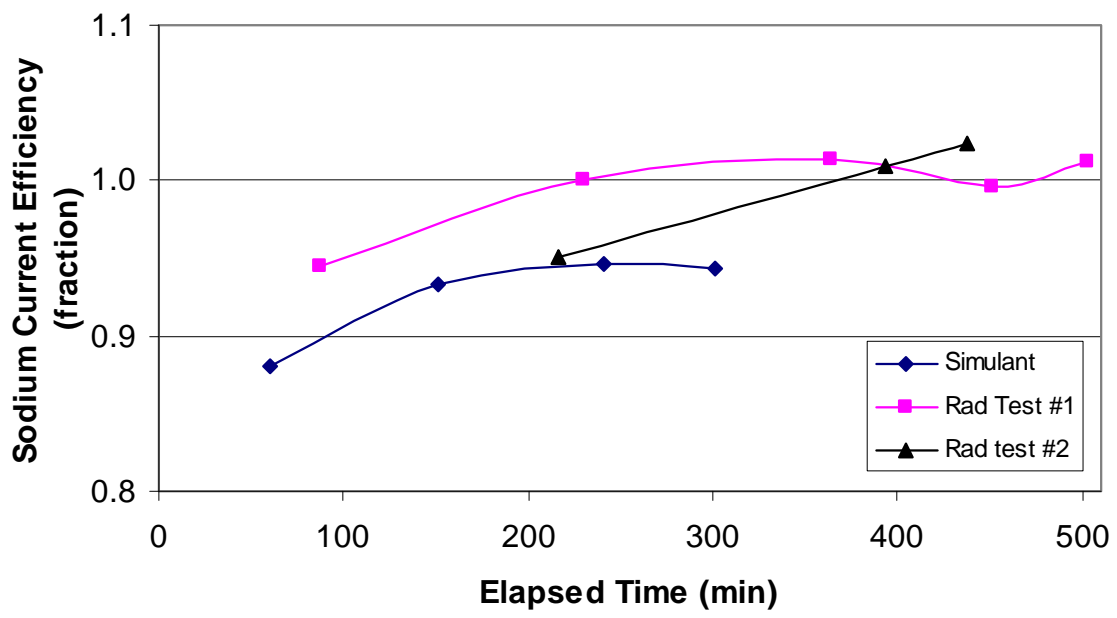

Figure 4.2. Comparison of Sodium Current Efficiency Between Tests

Aside from an initial drop in sodium transport efficiency, values were consistently high, indicating good reproducibility and effective power usage. Sodium transport rates, summarized in Table 4.1, were relatively consistent throughout testing and offer a basis for scaling up Na production processes to the industrial level to meet throughput requirements of the Waste Treatment Plant (WTP).

The selectivity (Equation 3.2) of the NAS-GY membrane towards sodium is an important performance parameter in the tank-waste treatment process because membrane selectivity towards undesirable cations and radionuclides degrade the purity of the recycled material $(19 \mathrm{M} \mathrm{NaOH})$ and can increase dose to operators. In both radiological experiments, no cations or anions except $\mathrm{Na}$ and trace quantities of $\mathrm{Cs}^{+}$were transported through the membrane. Na membrane selectivity with respect to ${ }^{137} \mathrm{Cs}$ was 384 in radiological test \#1 and 250 in radiological test \#2. These results demonstrate the NAS-GY membrane was several hundred times more selective to $\mathrm{Na}$ than ${ }^{137} \mathrm{Cs}$, and verify that o-ring and membrane integrity were maintained. 
Confidence in the conclusion that o-ring and membrane integrity were maintained was derived from GEA detection limits. Detection limits were generally better than $1 \mathrm{E}-4 \mu \mathrm{Ci} / \mathrm{mL}$ for all radionuclides investigated. Using the specific activity of ${ }^{137} \mathrm{Cs}(98 \mu \mathrm{Ci} / \mathrm{g})$, the detection limits were on the order of $1 \mathrm{E}-6 \mu \mathrm{g} / \mathrm{mL}$. These detection limits far exceed those of ICP-OES which are on average $0.022 \mu \mathrm{g} / \mathrm{ml}$ times a sample dilution factor. Best case detection limits would be a dilution factor of 1 .

Table 4.2 provides a slightly different look at the performance of the membrane towards the various radionuclides in the anolyte solution. The decontamination factor (Df) is frequently used in the radiological protection arena and represents the effectiveness of a decontamination process. In an electrochemical separation process, the Df is defined as the ratio of the initial radionuclide concentration in the anolyte and the final radionuclide concentration in the catholyte. Generally, Df values $>1,000$ are excellent while $<10$ are poor.

The extremely high decontamination factors observed during the present testing indicate that the caustic recycle process will generate a very-high-purity caustic product with dose rates approximately 2000 times less than the initial waste stream. It is important to note that the initial anolyte sample analyzed in Test \#2 contained precipitated solids and was obtained prior to re-dissolution of solids with $19 \mathrm{M} \mathrm{NaOH}$. The concentrations of ${ }^{154} \mathrm{Eu},{ }^{155} \mathrm{Eu},{ }^{126} \mathrm{Sn} / \mathrm{Sb},{ }^{241} \mathrm{Am}$ and ${ }^{90} \mathrm{Sr}$ appear to have been reduced significantly by the solids precipitation. For example, the initial concentration of ${ }^{241} \mathrm{Am}$ and ${ }^{90} \mathrm{Sr}$ in the anolyte both appear to have changed by $6.11 \mathrm{E}-4$ and 0.47 while detection limits of ${ }^{241} \mathrm{Am}$ and ${ }^{90} \mathrm{Sr}$ were $<1 \mathrm{E}-5$ and $<4 \mathrm{E}-5$, respectively. If the anolyte concentrations truly changed this much ${ }^{241} \mathrm{Am}$ and ${ }^{90} \mathrm{Sr}$ would have been detected in the catholyte sample analysis. Given this unexpected solids influence on the anolyte sample, the best estimate of the initial anolyte concentration for test \#2 is the initial anolyte concentration measured in Test \#1 minus any measured change. In future experiments, radionuclide analysis should not include samples with precipitated solids or the solids must be re-dissolved prior to analysis.

Table 4.2. Radionuclide Analysis and Decontamination Factors

\begin{tabular}{|c|c|c|c|c|c|c|}
\hline & \multicolumn{3}{|c|}{ Test 1 (1 M NaOH Catholyte) } & \multicolumn{3}{|c|}{ Test 2 (18.6 M NaOH Catholyte) } \\
\hline & $\begin{array}{c}\text { Anolyte } \\
\text { Initial } \\
(\mu \mathrm{Ci} / \mathbf{m L})\end{array}$ & $\begin{array}{c}\text { Catholyte } \\
\text { Final } \\
(\mu \mathrm{Ci} / \mathrm{mL})\end{array}$ & $\begin{array}{c}\text { Df } \\
\text { (initial/final) }\end{array}$ & $\begin{array}{c}\text { Anolyte } \\
\text { Initial } \\
(\mu / \mathrm{cu} / \mathrm{mL})\end{array}$ & $\begin{array}{c}\text { Catholyte } \\
\text { Final } \\
(\mu / \mathbf{c i} / \mathbf{m L})\end{array}$ & $\begin{array}{c}\text { Df } \\
\text { (initial/final) }\end{array}$ \\
\hline Total $\alpha$ & 8.66E-04 & nd & - & $1.21 \mathrm{E}-04$ & nd & - \\
\hline Total $\beta$ & $1.75 \mathrm{E}+00$ & $4.66 \mathrm{E}-05$ & 37446 & $6.11 \mathrm{E}-01$ & 7.04E-05 & 8679 \\
\hline${ }^{90} \mathrm{Sr}$ & $7.14 \mathrm{E}-01$ & nd & - & $2.44 \mathrm{E}-01$ & nd & - \\
\hline${ }^{99} \mathrm{Tc}$ & $6.85 \mathrm{E}-01$ & nd & - & $7.52 \mathrm{E}-01$ & nd & - \\
\hline${ }^{60} \mathrm{Co}$ & $1.53 \mathrm{E}-03$ & nd & - & $1.48 \mathrm{E}-03$ & nd & - \\
\hline${ }^{125} \mathrm{Sb}$ & $2.01 \mathrm{E}-03$ & nd & - & $1.84 \mathrm{E}-03$ & nd & - \\
\hline${ }^{126} \mathrm{Sn} / \mathrm{Sb}$ & $1.71 \mathrm{E}-03$ & nd & - & $1.30 \mathrm{E}-03$ & nd & - \\
\hline${ }^{137} \mathrm{Cs}$ & $3.00 \mathrm{E}-02$ & $1.28 \mathrm{E}-05$ & 2344 & $3.06 \mathrm{E}-02$ & $1.85 \mathrm{E}-05$ & 1654 \\
\hline${ }^{154} \mathrm{Eu}$ & $6.17 \mathrm{E}-04$ & nd & - & $1.11 \mathrm{E}-04$ & nd & - \\
\hline${ }^{155} \mathrm{Eu}$ & $2.37 \mathrm{E}-04$ & nd & - & $3.90 \mathrm{E}-05$ & nd & - \\
\hline${ }^{241} \mathrm{Am}$ & 7.09E-04 & nd & - & $9.78 \mathrm{E}-05$ & nd & - \\
\hline
\end{tabular}


The waste composition of the anolyte reservoir is of particular interest in assessing the potential for solids generation and the potential impact on downstream processes. GEA measurements indicated no radionuclide changes in the anolyte except for the transport of ${ }^{137} \mathrm{Cs}$ to the catholyte. ICP-OES measurements clearly indicated $\mathrm{Na}$ ion transport, but also identified a decreased concentration of $\mathrm{Al}, \mathrm{Ca}$, and $\mathrm{Si}$ in the samples taken after the large voltage increases occurred. These changes are illustrated in Table 4.3. An Al concentration decrease is expected from gibbsite precipitation due to the consumption of $\mathrm{OH}^{-}$and the resulting $\mathrm{pH}$ decrease. Si and Ca are observed to drop out as solids complexes as well. The precipitation of Si-based solid phases was reported previously by Hobbs (1999). Ion Chromatography (IC) analysis was completed on select catholyte and anolyte samples to determine any transport or composition changes related to $\mathrm{F}^{-}, \mathrm{Cl}^{-}, \mathrm{NO}_{2}^{-}, \mathrm{NO}_{3}{ }^{-}, \mathrm{SO}_{4}{ }^{-2}, \mathrm{CrO}_{4}^{-2}$, and $\mathrm{PO}_{4}^{-3}$ anions. No discernable transport of these anions was observed. However, approximately $30 \%$ of the original $\mathrm{NO}_{2}{ }^{-}$anions were oxidized to $\mathrm{NO}_{3}{ }^{-}$anions.

Table 4.3. Cation Concentration Decrease in Anolyte (ICP-OES Results)

\begin{tabular}{ccccccc}
\hline & \multicolumn{2}{c}{ Test 1 (1 M NaOH Catholyte) } & \multicolumn{2}{c}{ Test 2 (18.6 M NaOH Catholyte) } \\
\cline { 2 - 7 } & Initial $(\boldsymbol{\mu g} / \mathbf{m l})$ & Final $(\boldsymbol{\mu g} / \mathbf{m l})$ & \% change & Initial $(\boldsymbol{\mu g} / \mathbf{m l})$ & Final $(\boldsymbol{\mu g} / \mathbf{m l})$ & $\%$ change \\
\hline $\mathrm{Na}$ & 109000 & 94400 & $13 \%$ & 104500 & 90400 & $13 \%$ \\
$\mathrm{Al}$ & 7490 & 1480 & $80 \%$ & 7205 & 1760 & $76 \%$ \\
$\mathrm{Ca}$ & 45.2 & 23.7 & $48 \%$ & 40 & 20 & $50 \%$ \\
$\mathrm{Si}$ & 72.2 & 24.5 & $66 \%$ & 49 & 21.8 & $56 \%$ \\
\hline
\end{tabular}

During true Na production operations, the precipitation of solids would not be allowed because of possible system fouling or plugging. In both radiological tests, operations were shut down at the first visual observation of solids formation. These solids were identified in previous work (Hobbs 1999) as aluminum (gibbsite form) through XRD analysis. The formation of aluminum precipitate will ultimately dictate and limit the amount of sodium that can be removed. Therefore, predicting aluminate precipitation is important to the successful operation of a caustic recycle process. Understanding the equilibrium conditions between $\mathrm{Al}$ and hydroxide allows operators to maximize the amount of $\mathrm{Na}$ removed from the process stream while avoiding possible system fouling due to Al solids.

Misra (1970) developed an empirical model for the quantity of sodium hydroxide required to dissolve gibbsite from simulant data:

$$
\ln \left[\mathrm{Al}(\mathrm{OH})_{4}^{-}\right]=5.71-\frac{2486.70}{T}+\frac{33.71[\mathrm{NaOH}]}{T}+\ln [\mathrm{NaOH}]
$$

where $T$ is the temperature in Kelvin, $\left[\mathrm{Al}(\mathrm{OH})_{4}{ }^{-}\right]$is the concentration in solution, and $[\mathrm{NaOH}]$ is the total caustic concentration. Note that this equation was developed for pure sodium hydroxide solutions, and other anions will cause some increase in the aluminate solubility. Taking a conservative approach, the aluminate solubility in this work is based only on the measured free hydroxide concentrations. 
The Misra (1970) model delineates the point at which precipitation may start to occur. However, the rate of precipitation is equally significant, particularly if waste process streams become vitrified in a short time frame. Li and coworkers (2005) investigated crystal growth rates of saturated sodium aluminate solutions and established that the saturation ratio governed the precipitation rate of over-saturated aluminate solutions.

The saturation ratio was defined as the ratio of the aluminate concentration of the actual solution to the concentration at the solubility limit. This is shown in Equation 4.2. When the saturation ratio is less than one, the solution is under-saturated, and it is over saturated when the saturation ratio exceeds one.

$$
S R=\frac{\left[\mathrm{Al}(\mathrm{OH})_{4}^{-}\right]_{\text {actual }}}{\left[\mathrm{Al}(\mathrm{OH})_{4}^{-}\right]_{\text {saturation }}}
$$

where $S R$ is the saturation ratio of the solution, $\left[\mathrm{Al}(\mathrm{OH})_{4}^{-}\right]_{\text {actual }}$ is the actual concentration of $\left[\mathrm{Al}(\mathrm{OH})_{4}^{-}\right]$in solution $\left(\mathrm{mol} \mathrm{l}^{-1}\right)$, and $\left[\mathrm{Al}(\mathrm{OH})_{4}^{-}\right]_{\text {saturation }}$ is the concentration of $\left[\mathrm{Al}(\mathrm{OH})_{4}^{-}\right]$in solution at saturation from Equation $4.1\left(\mathrm{~mol} \mathrm{l}^{-1}\right)$.

Through Equations 4.1 and 4.2, both the conditions to initiate precipitation and the rate of precipitation can be determined. For example, an aluminate solution that is just saturated at $50^{\circ} \mathrm{C}$ will have a saturation ratio of 1.8 at $25^{\circ} \mathrm{C}$. A heated leachate solution that is saturated at $100^{\circ} \mathrm{C}$ will have a saturation ratio from 4 to 5 (depending on the sodium hydroxide concentration) when cooled to $25^{\circ} \mathrm{C}$.

Li and coworkers (2005) measured crystal-growth-rate data, and these data show that the crystal growth rate for these solutions varies exponentially with the saturation ratio. In general, the measured precipitation rates were slow, being under $1 \mathrm{~nm} / \mathrm{min}$ at a saturation ratio of eight and trending toward 0 at a saturation ratio of one.

A power-law fit of the data shown in Figure 4.3 was used to predict the time needed to precipitate gibbsite particles of various diameters. A residence time on the order of 1 week is assumed. Preventing large, process-impacting particles (greater than 10 microns) from forming in the process corresponds to a maximum particle-size range of 1 to 10 microns forming over the average residence time of one week. In this analysis, a target saturation ratio range of 1.5 to 8 is determined for process compatibility. In a fullscale production process, the separation cells would operate in a continuous process mode (not batch), and these high saturation ratios would not be approached.

Figure 4.4 and Figure 4.5 display the sodium transported as a function of saturation ratio during radiological test $\# 1$ and radiological test $\# 2$. In both cases, we observe a sharp voltage change after the saturation ratio reaches or exceeds 9 to 10. This finding supports a successful operation up to saturation ratios of 8 . The cell was also successfully operated at saturation ratios as high as 12 . Further, samples obtained for chemical analysis were monitored for any solids precipitation since testing was completed. All samples obtained prior to reaching a saturation ratio of 10 remained clear of any solids. Therefore, this prediction approach appears useful, however, the influence of anions on the aluminate solubility must be better understood to assure safe operation. 


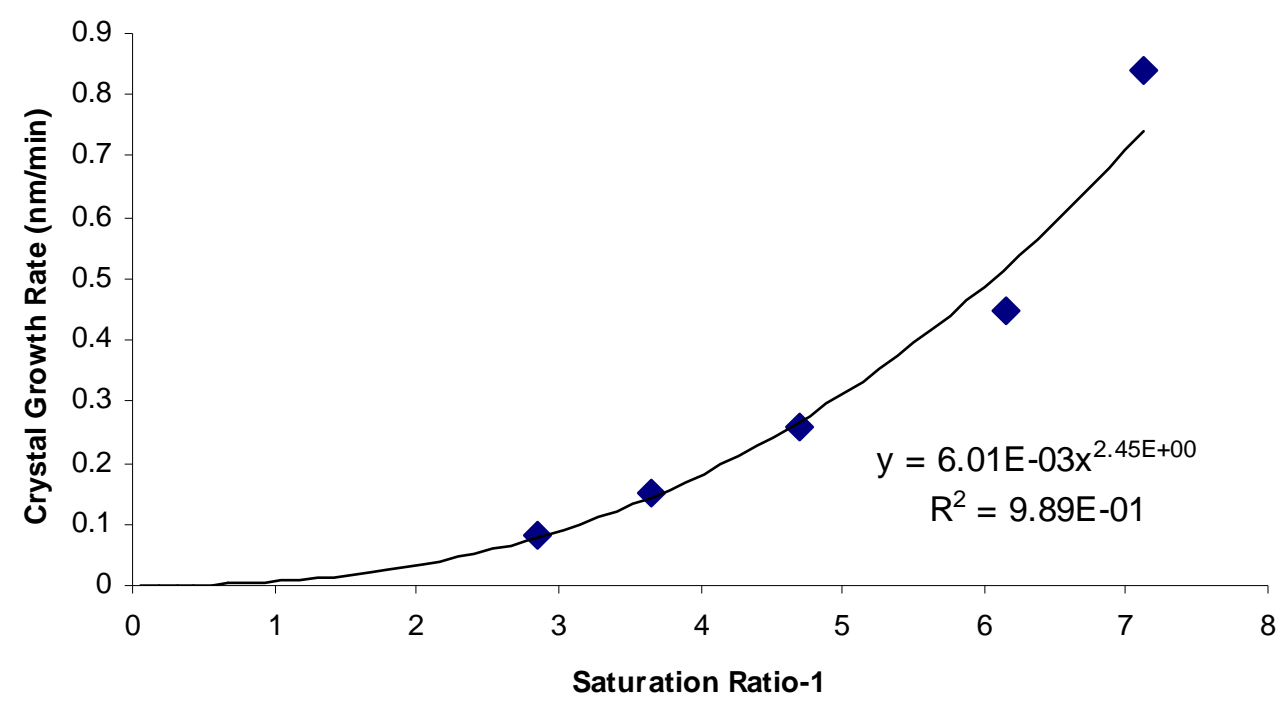

Figure 4.3. Experimentally Measured Crystal Growth Rates of Saturated Sodium Aluminate Solutions at $22^{\circ} \mathrm{C}$

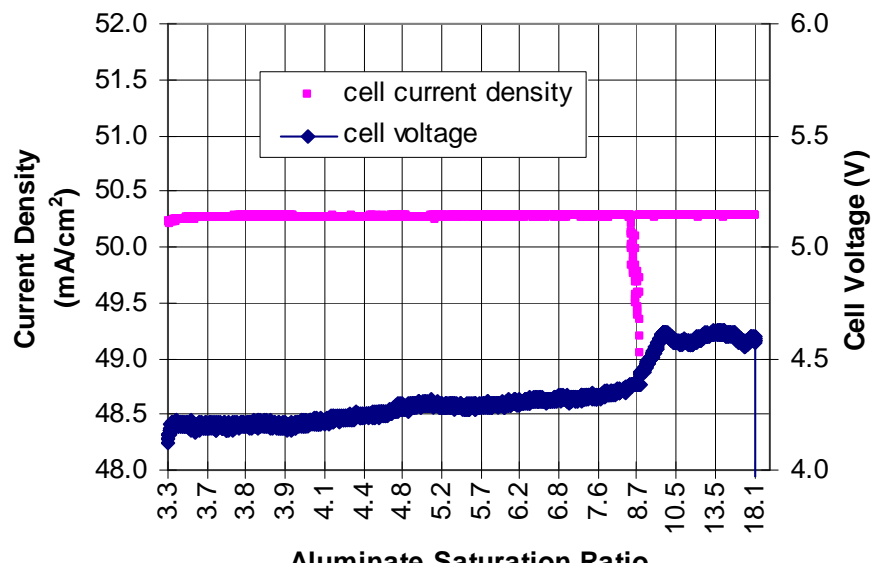

Figure 4.4. Voltage and Current Density as a Function of Saturation Ratio during Rad Test \#1

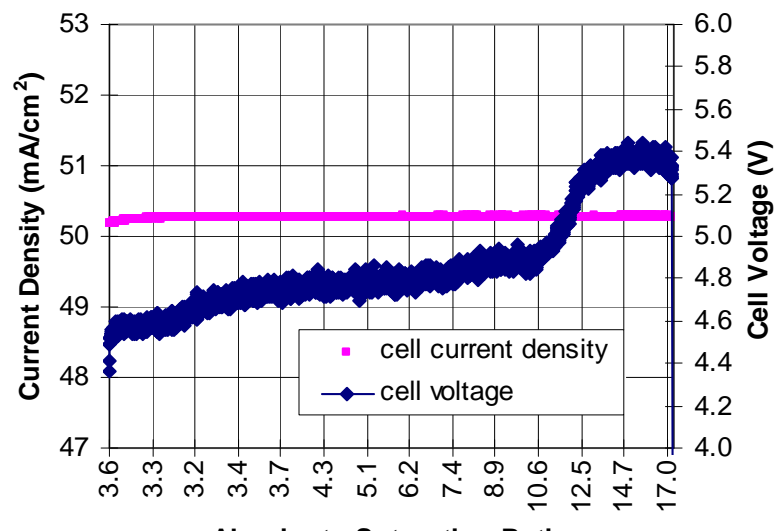

Aluminate Saturation Ratio

Figure 4.5. Voltage and Current Density as a Function of Saturation Ratio during Rad Test \#2 



\subsection{Conclusions}

A NaSICON membrane, with a proprietary NAS-GY formulation, was electrochemically tested in a bench-scale apparatus with both a simulant and radioactive tank-waste solutions to determine the membrane performance when removing sodium from Hanford tank waste samples. Conclusions from these experiments are as follows:

- Sodium transport efficiencies ranged from 88 to $102 \%$ while average efficiencies were $93 \%$ (nonradioactive test) and $99 \%$ (both radioactive tests). The membrane appears to undergo an initial "break-in" period, which is assumed to be a transition from an unsaturated to a saturated $\mathrm{Na}$ channel network.

- All three experiments produced $\mathrm{Na}$ transport rates in good agreement with theoretical $\mathrm{Na}$ transport rates based on applied current. Average Na separation rates of $9.6 \mathrm{~kg} / \mathrm{day} / \mathrm{m}^{2}$ (simulant$1 \mathrm{M} \mathrm{NaOH}), 10.3 \mathrm{~kg} /$ day $/ \mathrm{m}^{2}$ ( $\left.\mathrm{rad}-1 \mathrm{M} \mathrm{NaOH}\right)$, and $10.3 \mathrm{~kg} /$ day $/ \mathrm{m}^{2}(\mathrm{rad}-18.6 \mathrm{M} \mathrm{NaOH})$ were observed.

- The NAS-GY membrane is highly selective to sodium. No transport of any cations or anions was detected except for $\mathrm{Na}$ and ${ }^{137} \mathrm{Cs}$. Decontamination factors on the order of 2000 were observed with respect to ${ }^{137} \mathrm{Cs}$.

- ICP-OES measurements clearly indicated $\mathrm{Na}$ ion transport, but also identified a decreased concentration of $\mathrm{Al}, \mathrm{Ca}$, and $\mathrm{Si}$ in the samples taken after the large voltage increases occurred.

- The electrochemical cell system successfully produced a $19 \mathrm{M} \mathrm{NaOH}$ solution with no observable membrane performance loss. In addition, concentrating the $\mathrm{NaOH}$ product to $19 \mathrm{M} \mathrm{NaOH}$ satisfies the feedstock caustic requirement of DOE's WTP and would eliminate the need for a process evaporator when using other separation technologies.

- The anion waste composition of the anolyte reservoir was relatively stable. There was no discernable transport or composition changes related to $\mathrm{F}^{-}, \mathrm{Cl}^{-}, \mathrm{NO}_{2}^{-}, \mathrm{NO}_{3}^{-}, \mathrm{SO}_{4}^{-2}, \mathrm{CrO}_{4}^{-2}$, and $\mathrm{PO}_{4}^{-3}$ anions except approximately $30 \%$ of the original $\mathrm{NO}_{2}{ }^{-}$anions were oxidized to $\mathrm{NO}_{3}{ }^{-}$anions.

- A maximum recoverable sodium quantity could be predicted by combining both an aluminate solubility model and a gibbsite crystal growth rate. Testing shows cell voltages were relatively stable until saturation ratios exceeded 9 (sharp increase in voltage), and the cell was successfully operated at saturation ratios as high as 12 . 



\subsection{References}

Davis NR. 1998. High-Level Waste System Plan Revision 9 (U). HLW-OVP-98-0037, Westinghouse Savannah River Co., Aiken, South Carolina.

Hobbs DT. 1999. "Caustic Recovery from Alkaline Nuclear Waste by an Electrochemical Separation Porcess." Separation and Purification Technology 15:239-253.

Kirkbride RA, GK Allen, PJ Certa, GT MacClean, AF Manuel, RM Orme, DL Penwell, LW Shelton, EJ Slaathaug, and RS Wittman. 1997. Tank Waste Remediation System Operation and Utilization Plan. HNF-SD-WM-SP-012 Revision 0, Numatec Hanford Company, Richland, Washington.

Kirkbride RA, GK Allen, PJ Certa, JA Lechelt, and SL Orcutt. 2005. Hanford Tank Waste Operations Simulator Model Data package for the Development Run for the Refined Target Case. RPP-RPT-23412 Rev 1, CH2M Hill Hanford Group Inc, Richland, Washington.

Kurath DE, GW Hollenberg, J Jue, J Smith, AV Virkar, S Balagopal, and V Sutija. 1997a. "Salt splitting using ceramic membranes." Sep. Sci. Tech. 32:557-572.

Kurath DE, KP Brooks, GW Hollenberg, R Clemmer, S Balagopal, T Landro, and DP Sutija. 1997b. Preconceptual Design of a Salt Splitting Process Using Ceramic Membranes. PNNL-11454, Pacific Northwest National Laboratory, Richland, Washington.

Kurath DE, KP Brooks, GW Hollenberg, (PNNL), DP Sutija, T Landro, S Balagopal (Ceramatec), 1997c. "Caustic Recycle from High-salt Nuclear Wastes Using a Ceramic-membrane Salt-splitting Process." Separation and Purification Technology 11:185-198.

Li H, J Addai-Mensah, JC Thomas, and AR Gerson. 2005. "The influence of Al(III) supersaturation and $\mathrm{NaOH}$ concentration on the rate of crystallization of $\mathrm{Al}(\mathrm{OH}) 3$ precursor particles from sodium aluminate solutions." Journal of Colloid and Interface Science 286:511-519.

Maximov BA, Petrov IV, Rabenau A, and Schulz H. 1982. "X-Ray Investigations and Possible Mechanism for the Ionic Conductivity in the $\mathrm{Na}_{5} \mathrm{RESi}_{4} \mathrm{O}_{12}(\mathrm{RE}=\mathrm{Y}, \mathrm{Sc})$ Class of Compounds." Sol. St. Ion. 6:195-200.

Misra C. 1970. "Methods, apparatus: new product research, process development and design." Chemistry and Industry 1:219-223.

Strathmann H. 1992. "Ion-Exchange Membranes.” In: Membrane Handbook. WS Winston Ho and KK Sirkar (Eds.). Chapman \& Hall, New York.

Sutija DP, S Balagopal, T Landro, and J Gordon. 1996. "Ceramic cleansers: environmental applications of sodium super-ionic conducting ceramics." The Electrochemical Society Interface 5(4):26. The Electrochemical Society, Pennington, New Jersey. 



\section{Distribution}

No. of

Copies

\# Name

Organization

Address

City, State and ZIP Code

\# Organization

Address

City, State and ZIP Code Name

Name

Name

Name

Name (\#)

\# Name

Organization

Address

City, State and ZIP Code
No. of

Copies

\# Foreign Distribution

\# Name

Organization

Address

Address line 2

COUNTRY

\# Local Distribution

Pacific Northwest National Laboratory

Name

Name

Mailstop

Mailstop

Name

Mailstop

Name

Mailstop

Name 


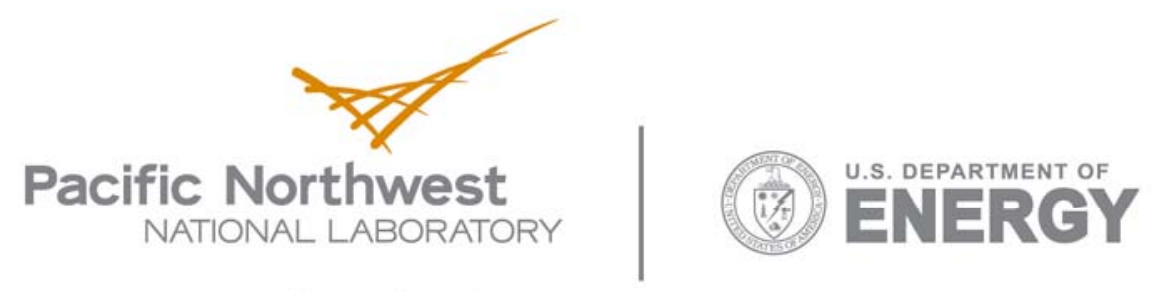

902 Battelle Boulevard

P.O. Box 999

Richland, WA 99352

1-888-375-PNNL (7665)

www.pnl.gov 